\title{
Paternal care in rodents: Ultimate causation and proximate mechanisms
}

\section{Vladimir S. Gromov}

\begin{abstract}
The evolution of paternal care in rodents has intrigued biologists for over decades. In this paper, both ultimate (adaptive significance, evolution) and proximate (ontogeny, mechanisms) questions related to the emergence and maintenance of male paternal care are reviewed. Paternal care is thought to be a consequence of social monogamy, but no definitive hypothesis adequately explains the evolution of paternal behavior in rodents. The onset, activation and maintenance of paternal care are shown to be governed by complex interactions in neuroendocrine systems that change during ontogeny. Depending on the species, different components of male experience as well as different exogenous cues are likely to be involved in the organization and activation of paternal behavior. Several hormones, including steroids (testosterone, estradiol, progesterone) and neuropeptides (prolactin, vasopressin, oxytocin), are involved in the onset, the maintenance, or both the onset and the maintenance of parental behavior, including direct paternal care. The effect of testosterone was found to be not universal and, moreover, species-specific. As for estrogens and neuropeptides, further investigations are needed to better understand the role of these hormones in activation and maintenance of rodent paternal behavior. Current research shows that male parental care in rodents is, to a great extent, an epigenetic phenomenon, and future studies will focus on the epigenetic modifications that can affect the paternal behavior in rodents.
\end{abstract}

How to cite this article: Gromov V.S. 2020. Paternal care in rodents: ultimate causation and proximate mechanisms // Russian J. Theriol. Vol.19. No.1. P.1-20. doi: 10.15298/rusjtheriol.19.1.01.

KEY WORDS: rodents, paternal care, ultimate causes, proximate mechanisms.

Vladimir S. Gromov [vsgromov@mail.ru], A.N. Severtsov Institute of Ecology and Evolution, Russian Academy of Sciences, Leninsky pr. 33, Moscow 119071, Russia.

\section{Забота о потомстве у самцов грызунов: эволюционное происхождение и проксимальные механизмы стимуляции}

\section{В.С. Громов}

РЕЗЮМЕ. Вопросы, связанные с эволюцией родительского поведения у самцов грызунов, интересуют биологов уже многие десятилетия. В статье рассматривается адаптивное значение и эволюционное происхождение отцовского поведения у разных видов грызунов, а также проксимальные механизмы его стимуляции и регуляции. Полагают, что забота о потомстве у самцов млекопитающих, в том числе грызунов, есть прямое следствие моногамных социальных отношений, однако ни одна из существующих гипотез не дает удовлетворительного объяснения эволюции отцовского поведения. Современные исследования показывают, что проявление заботы о потомстве у самцов обеспечивается сложным взаимодействием нервной и эндокринной систем в ходе онтогенетического развития. Кроме того, родительское поведение самцов зависит от различных экзогенных и эндогенных факторов. Ряд гормонов, в том числе половые стероиды (тестостерон, прогестерон и эстрадиол) и нейропептиды (пролактин, окситоцин и вазопрессин), вовлечен в сложный процесс стимуляции и регуляции отцовского поведения. Установлено, что тестостерон в этом процессе играет не однозначную роль, и его влияние на поведение самцов является видоспецифическим. Что касается эстрогенов и нейропептидов, то их роль в стимуляции и регуляции отцовского поведения изучена пока неудовлетворительно, поэтому возникает необходимость в дополнительных исследованиях. Как показывают исследования последних лет, забота о потомстве у грызунов — в значительной степени эпигенетический феномен, требующий детального и обстоятельного изучения.

КЛЮЧЕВЫЕ СЛОВА: грызуны, отцовское поведение, эволюция, проксимальные механизмы. 


\section{Introduction}

Male parental care is relatively rare among mammals (Kleiman, 1977; Kleiman \& Malcolm, 1981), because males typically are 'emancipated' from care of young and have the first opportunity to seek additional mates (Orians, 1969; Trivers, 1972; Maynard-Smith, 1977; Clutton-Brock, 1991). Moreover, males would forfeit potential reproductive success if they increased their parental effort in any one female's young at the expense of lost mating opportunities (Kurland \& Gaulin, 1984). Nevertheless, male care of young does exist in some mammalian species, including rodents. This is why there is considerable recent interest in the evolution of male parental care.

In rodents, male parental care is typical of biparental species. This kind of male reproductive strategy is generally associated with social monogamy and can involve such behaviors as warming, feeding, protecting, retrieving, and grooming young, depending on the species (Kleiman \& Malcolm, 1981). Paternal care is related to a reduced likelihood of engaging in competitive or mating behavior and an increased likelihood of providing protection when necessary. Paternal behaviors include direct care of young (warming, huddling, retrieving, and grooming), as well as indirect care-giving activities (nest-building, provision of food, defense of the offspring against predators or infanticide); of course, males need to suppress their own infanticidal behavior in the presence of pups (Elwood, 1977; Perrigo et al., 1991; Vella et al., 2005; Wynne-Edwards \& Timonin, 2007). In some rodent species, males show levels of direct parental care comparable to those of females (Elwood, 1983; Dewsbery, 1985; Brown, 1993; Gromov, 2011a).

The nature of paternal care both within a species and among different species exhibits phenotypic plasticity: it is shaped by ecological provisions, environmental factors, neural constraints, and species-specific social interactions (Westnead \& Sherman, 1993; Reynolds et al., 2002; Royle et al., 2014; Rosenbaum \& Getter, 2018). In this article, the proximate and ultimate factors affecting rodent paternal behavior will be considered.

\section{Ultimate causation of male parental care}

As paternal investment is very costly, in terms of reduced survival, breeding and mating opportunities (Clutton-Brock, 1991), the question is why paternal care evolved in those species where it is observed. It is suggested that male parental care will only evolve when there is environmentally induced selection for care, and males are capable of improving offspring survival and development to such an extent that the benefits of paternal investment outweigh the costs of lost mating opportunities (Emlen \& Oring, 1977; Kleiman \& Malcolm, 1981; Gubernick \& Teferi, 2000; McGuire, 2003; Wynne-Edwards, 2003; Feldman et al., 2019). Male parental care appears to have evolved multiple times among different taxa of rodents (Kalcounis-Rüppel \& Ribble, 2007; Lukas \& Clutton-Brock, 2013). It means that various environmental factors may operate as selective forces promoting the evolution of paternal care in different species. Paternal behavior is not restricted to specific phylogenetic lineages, hence it has evolved within individual species in response to local ecological conditions that demand care from two parents to optimize the reproductive success of each (Wynne-Edwards, 2003).

In general, two broad groups of hypotheses are proposed for mammals, which could explain the evolution of paternal care in rodents. Fitness-enhancing hypotheses (Trivers, 1972; Maynard-Smith, 1977) suggest that paternal care evolved because there was an initial direct benefit to offspring, fathers and/or mothers. The prevailing paradigm assumes that a male's fitness can increase through providing care if his offspring survive and reproduce, and certainty of paternity is presumably a contributor to the evolution of paternal care. However, certainty of paternity is shown to be not required for paternal care in rodents (Hartung \& Dewsbury, 1979; Werren et al., 1980). Therefore, male fitness benefits do not adequately explain the evolution of paternal care among rodents.

On the other hand, paternal care can contribute to offspring survival, growth and/or development (Maynard-Smith, 1977) when resources are limited (Gubernick \& Teferi, 2000) or there is a risk of infanticide (Sommer, 1997), as well as in some other situations (Storey \& Snow, 1987; Brown, 1993; Huber et al., 2002; Stockley \& Hobson, 2016). However, male parental care is suggested to be not necessarily crucial for infant survival in any rodent species, and thus can not enhance the male fitness (Rymer \& Pillay, 2018).

Paternal care could also evolve directly through alleviating reproductive costs of females (West \& Capellini, 2016). Males making energetic contributions (e.g., provisioning food or huddling offspring) enable females to redirect resources into reproduction (Woodroffe \& Vincent, 1994) or foraging (Helmeke et al., 2009), although such a reduction in maternal workload is not ubiquitous across rodent taxa (West \& Capellini, 2016). Consequently, female fitness benefits are not the sole explanation for the evolution of paternal care in rodents. Therefore, the fitness-enhancing hypotheses in isolation do not account for the evolution of male parental care in rodents.

Another group of theoretical models, the constraints hypotheses (Rymer \& Pillay, 2018), suggest that paternal care evolved in the absence of fitness-related benefits, but males were constrained to remain with females and/ or offspring due to extrinsic (ecological) or intrinsic (physiological) constraints. In particular, the social constraints hypothesis (Payne \& Payne, 1993) assumes that limiting resources favor males defending exclusive territories, into which females disperse, leaving little opportunity for additional matings; social tolerance and paternal care could emerge consequently in this situation. The ecological constraints hypothesis (Maher \& Burger, 2016) suggests that under limiting resources, clumping of individuals due to costs associated with dispersal into potentially resource-poor environments could lead 
to mate guarding (or harem defense) and paternal care. Considering the constraints hypotheses, the extent of paternal care and its subsequent cost to males likely varies among individuals and species across ecological conditions due to historical and physiological processes (Requena \& Alonzo, 2017). Therefore, these hypotheses in isolation do not adequately explain why paternal care has not evolved in rodents generally.

It is also expected that assistance provided by males may allow females to produce more energetically costly litters, and the need for such male care contributes to the development of obligate social monogamy or communal breeding associated, in some species, with male parental care (Woodroffe \& Vincent, 1994). Social monogamy is known to be a social system when a single breeding female and a single breeding male share a common home range or territory and associate with each other for more than one breeding season, with or without non-breeding offspring (Lukas \& Clutton-Brock, 2013).

Theoretically, reduced opportunities for males to gain control of more than one female can lead to, as mentioned above, a monogamous mating system involving some forms of paternal care (Emlen \& Oring, 1977; Kleiman, 1977; Wittenberger \& Tilson, 1980; Lukas \& Clutton-Brock, 2013). In other words, social monogamy is considered to be the common evolutionary antecedent to the evolution of biparental care and, consequently, male parental care. In rodents, social monogamy is usually not associated with genetic monogamy, and the incidence of extra-pair mating is generally high in many socially monogamous species (see, for example, Solomon et al., 2004; Gromov, 2018). It is also suggested that social monogamy evolved in mammals where feeding competition between females was intense, breeding females were intolerant of each other, and population density was low (Lukas \& Clutton-Brock, 2013). This hypothesis however is not well supported by studies on rodents.

Recent phylogenetic reconstructions have demonstrated that paternal care is likely a by-product of social monogamy, which may have emerged as a form of mate guarding when the cost of mate searching was very high. Under these conditions, guarding individual females may represent the most efficient breeding strategy for males (Lukas \& Clutton-Brock, 2013).

Complementary analyses have also shown that across mammals, including rodents, various types of male parental care reduce female energetic burdens, especially during lactation (Stockley \& Hobson, 2016; West \& Capellini, 2016). Paternal care thus allows females to redirect effort from current young to future reproduction. While these theoretical and empirical contributions provide important insight into the evolution of paternal care, they do not negate the evidence that males in some non-monogamous species have social bonds with infants, and may make important contributions to their survival and growth. This is, for example, documented in striped mice, Rhabdomys pumilio (Schubert et al., 2009). The fact that paternal care occurs in non-monogamous systems additionally supports suggestions that it may have multiple evolutionary origins.
Because no single hypothesis is sufficient to explain all known instances of monogamy in mammals, including rodents, Wittenberger and Tilson (1980) proposed several alternative hypotheses for the evolution of this social system: 1) monogamy should evolve when male parental care is both non-shareable and indispensable to female reproductive success; this hypothesis implies that monogamy is advantageous for both sexes; 2) monogamy should evolve in territorial species if pairing with an unavailable unmated male is always better than pairing with an already mated male; 3 ) monogamy should evolve in non-territorial species when the majority of males can reproduce most successfully by defending exclusive access to a single female; 4) monogamy should evolve even though the polygyny threshold is exceeded if aggression by mated females prevents males from acquiring additional mates; 5) monogamy should evolve when males are less successful with two mates than with one.

Three hypotheses (2-4), according to Wittenberger and Tilson (1980), appear sufficient to explain all cases of monogamy in mammals, and hypotheses 2 or 4 may apply to rodents. For example, monogamous California mice (Peromyscus californicus) and grasshopper mice (Onychomys torridus) are territorial, and both sexes are highly aggressive toward intruders (Horner \& Taylor, 1968; Ribble \& Salvioni, 1990). By the way, territoriality and aggression toward intruders are typical of many rodent species with a family-group lifestyle (Gromov, 2008). Pair bonds are known to be maintained in beavers (Castor spp.) and muskrats (Ondatra zibethicus) by female aggression (Brady \& Svendsen, 1981; Hodgdon \& Lancia, 1983; Marinelli \& Messier, 1993).

Surprisingly, no mammals, according to Wittenberger and Tilson (1980), are monogamous because male parental assistance is essential for rearing offspring (hypothesis 1). This conclusion contradicts the results of the study on California mice (Gubernick et al., 1993; Gubernick \& Teferi, 2000; Wright \& Brown, 2002) showing that paternal presence significantly enhances offspring survival. Moreover, paternal care-giving has been shown to be beneficial in some other rodent species, being associated with a significant positive effect on pup growth, development and survival that enhances the male fitness (Storey \& Snow, 1987; Brown, 1993; Huber et al., 2002; Stockley \& Hobson, 2016). Besides, male parental care is thought to be advantageous for lactating females in Djungarian hamsters, Phodopus campbelli (Walton \& Wynne-Edwards, 1997; Wynne-Edwards, 2003). Thus, paternal behavior, associated with social monogamy, is certainly advantageous for both sexes in some rodent species.

Wittenberger and Tilson (1980) consider monogamy and polygyny as mutually exclusive reproductive strategies evolved under different selective pressures. However, in populations of some rodent species like, for example, the prairie vole (Microtus ochrogaster), the Mongolian gerbil (Meriones unguiculatus), the social vole (Microtus socialis), the Brandt's vole (Lasiopodomys brandti) or the muskrat, there are both monogamous and polygynous social units (Getz et al., 1993; Marinelli \& 
Messier, 1993; Roberts et al., 1998; Gromov, 2008, 2018). Therefore, the abovementioned hypotheses are incapable of explaining all known instances of social monogamy in rodents.

The ecological conditions leading to monogamy associated with biparental care-giving, and, consequently, paternal care, are debated. There is a point of view that monogamous species tend to dwell in stable environments, give birth to altricial offspring and have low reproductive potentials (Eisenberg, 1965; Emlen \& Oring, 1977; Kleiman, 1977). It has been also hypothesized that social monogamy evolved from the ancestral condition of solitary individuals on the background of female-female intolerance and female dispersion that increases motivation of males to defend their access to females and led to the formation of male-female monogamous units (Lukas \& Clutton-Brock, 2013). Besides, all the socially monogamous rodent species are territorial, and territoriality is thought to stabilize the "evolutionary stable strategy' (in the sense of Maynard-Smith, 1982) of paternal care once it has evolved. But territoriality could be secondarily evolved after paternal care (Ridley, 1978). On the other hand, according to Emlen (1982), family-group social organizations associated with biparental care may occur in variable and unpredictable environments and/ or under intense intra-specific competitive pressures in stable environments. Monogamy may be also common in populations where individuals are widely dispersed over relatively uniform environments (Emlen \& Oring, 1977). However, while ecological constraints are thought to be clearly important determinants of the available reproductive options in some biological systems, paternal care is found to be distributed across a wide variety of ecological niches in rodents. Some biparental rodent species inhabit areas showing a high degree of environmental stability and predictability, while others inhabit harsh, fluctuating, and highly unpredictable environments. Thus, paternal care emerges in both very harsh, variable niches and more stable, benign ones (Shen et al., 2017).

One of the abovementioned hypotheses suggests that paternal care may occur in situations in which this behavior is critical for the survival of the offspring (Emlen \& Oring, 1977; Clutton-Brock, 1989; Ribble, 2003). In these situations, males do not have the opportunity to seek additional mates, and their strategy for maximizing reproductive success is to maximize offspring survival. Such a reproductive strategy is documented, for instance, in California mice and old-field mice, Peromyscus polionotus (Wolff, 1989). As for California mice, male parental behaviors, like grooming, retrieving, and huddling over pups, are thought to be critical to offspring survival, especially when the ambient temperature is cold or resources are low (Gubernick \& Teferi, 2000; Ribble, 2003). Specifically, removal of male significantly decreased pup survival, suggesting that direct paternal care and not infanticide prevention (no other males were present) is the primary function of male care (Gubernick \& Teferi, 2000). Similar advantages of direct paternal care are found in mound-building mice, Mus spicilegus (Patris \& Baudoin, 2000).
Male parental care, which is typical of many rodent species with a family-group lifestyle belonging to the Holarctic fauna (Gromov, 2017, 2018), may have evolved as an adaptation to harsh environments, in which pair bonding and cooperation in different activities (digging of burrows or construction of other shelters, maintenance of territories, food hoarding, care of young) essentially increase offspring survival (Gromov, 2017, 2018). Geographic variation in paternal behavior reported for some rodent species (McGuire \& Bemis, 2007) seems to correlate also with harsher environmental conditions, particularly colder temperatures. Even some non-monogamous species, like meadow voles, Microtus pennsylvanicus, may have evolved the ability to form selective partner preferences and display paternal care in winter (Storey \& Snow 1987, Parker \& Lee, 2001a). This hypothesis emphasizes the role of cooperation in favoring a family-group lifestyle in rodents and, consequently, the emergence of biparental care (Gromov, 2014, 2018).

The distribution of resources or females may also affect the social structure and mating systems in rodent populations (Emlen \& Oring, 1977). When important resources are distributed uniformly in space, there is little opportunity for resource monopolization. If the resources are sufficiently abundant and stable through time, territoriality typically occurs. Under such conditions, members of the breeding population would tend toward even dispersion, and the potential for multiple matings would be low. Sexual selection would be minimal, and the fitness of individuals might be maximized by sharing equally in parental care. Monogamy, associated with male parental care, is thought to occur only in populations where individuals are widely dispersed over relatively uniform environments (Emlen \& Oring, 1977 ) or at the lowest densities with the lowest patchiness of food resources (Slobodchikoff, 1984; Waterman, 2007). In other words, paternal care accompanies social monogamous long-term bonds in situations when males are unable to gain access to more than one female during a mating season (Holmes, 1984; Komers \& Brotherton, 1997). While such situations are documented in a number of muroid rodents (Kleiman, 1977; Mihok, 1979; Wolff, 1985; Lambin \& Krebs, 1991; Getz et al., 1993; Waterman, 2007), they however primarily result in the facultative monogamy typical of many rodent species in which males usually do not contribute to paternal care. Thus, the relationship between the evolution of social monogamy associated with male parental care and distribution of resources, including mates, demands a more reliable substantiation in rodents.

As for other factors favoring the evolution of parental behavior, Ribble (2003) suggested that relative litter weight might be correlated with the need for paternal care and influences male mating strategies. It was shown, in particular, that males of species with low relative litter weights tended to be monogamous, and, consequently, exhibited different paternal behaviors.

Some authors suggested the specific ecological conditions favoring paternal responsiveness in certain rodent species. For example, male presence was supposed to 
alleviate maternal hyperthermia, which is a particular challenge in Djungarian hamsters, $P$. campbelli, adapted to heat retention rather than heat dissipation, and thereby preserves maternal homeostasis (Walton \& WynneEdwards, 1997; Wynne-Edwards, 2003). The evolution of paternal care in P. campbelli is seen as the necessary consequence of conflict between adaptations for survival in a cold, dry seasonal habitat and reproductive adaptations appropriate for handling heat load, water stress, and rapid breeding in the same habitat. Moreover, the authors of this hypothesis (Wynne-Edwards, 2003; Wynne-Edwards \& Timonin, 2007) have proposed the unique, hormone-independent (see below) pathways to paternal behavior that has possibly evolved in P. campbelli. This hypothesis however does not explain why male parental care is not evolved in other dwarf hamster, Phodopus sungorus, adapted to the same environmental conditions of Central Asia.

To summarize, one can conclude that the literature related to the ultimate causation of rodent paternal care remains replete with a variety of interpretations and subject to a fair amount of debate. Neither purely phylogenetic nor socio-ecological hypotheses can explain presence or variability in the expression of paternal behaviors in rodents. It is obvious that no one set of circumstances has led to the parallel evolution of biparental care in rodents. This poses a paradox: why do similar social organizations occur in such seemingly opposite ecological situations? This question has no distinct answer to date.

\section{Proximate mechanisms of male parental} care

A concern with understanding proximate mechanisms of paternal care is that much of our understanding results from studies of laboratory rats and mice that are not naturally paternal. While some studies on naturally paternal species support the studies on laboratory rodents, the existence of a universal proximate mechanism across and within taxa is unlikely, and might be species-specific (Rymer \& Pillay, 2018). In recent years, considerable progress has been made in elucidating developmental, social, hormonal, and neural determinants of paternal behavior, primarily in naturally biparental rodents. Much of this work has focused on determinants of within-animal changes in males' responses to pups across the lifespan: males of some species undergo predictable changes in their behavioral responses to pups, transitioning between aggression, indifference, and nurturance at different life stages. Depending on the species, different components of male experience as well as different exogenous cues are likely to be involved in the organization and activation of paternal behavior. These exogenous stimuli must then activate the central nervous system to evoke the needed learning and behavior.

Among the exogenous stimuli, maternal response is known to be one of the main factors influencing the level of paternal care. In other words, a major determinant of paternal behavior is whether or not the female permits the male to stay near the young (Dewsbury, 1985). For example, females of some biparental species, like the Mongolian gerbil, the grasshopper mouse, the prairie vole, and the spiny mouse (Acomys cahirinus), frequently exclude males from the natal nest during parturition and for about a day thereafter, but subsequently permit males to fully interact with young (Elwood, 1975; McCarty \& Southwick, 1977; Porter et al., 1980; McGuire et al., 2003). In contrast, presence of the mother was found to maintain paternal responsiveness in California mice, and maternal excreta were sufficient to keep fathers parental (Gubernick \& Alberts, 1989). If the male remains with the female and the offspring it may generally be to the male's advantage to act parentally. Hence, male presence could be a strong predisposing factor for paternal behavior (Dewsbury, 1985).

There are also so called indirect genetic effects that occur when variation in the quality of the environment (e.g., in the nest) provided by parents reflects genetic differences among them (Wolf et al., 1998). Environmental effects derived from this parental variation are considered 'inherited environments' because the parental phenotypes producing these environmental effects in offspring could be heritable (Wolf et al., 1998). Paternal effects are specific indirect genetic effects derived from the environment provided by fathers. They occur when fathers are influenced by environmental factors, which impact offspring (Curley et al., 2011). Paternal effects also occur when fathers influence maternal care of their mates. In particular, the father's absence can lead to reduced or increased maternal care (Helmeke et al., 2009; Rymer \& Pillay, 2011). In striped mice, females compensate for a lack of paternal help when raising offspring alone, resulting in adult sons providing more care to their own offspring (Rymer \& Pillay, 2011).

On their first exposure to infants, male rodents may be infanticidal, show parental behavior or ignore the pups. Whether or not they show parental behavior may be influenced by their experience with infants (Jakubowski \& Terkel, 1985; Soroker \& Terkel, 1988). Such an experience resulting in emergence of paternal responsiveness is known as sensitization (Brown, Moger, 1983; Dewsbury, 1985; Walsh et al., 1996) and will be considered separately (see below).

In evolutionary terms, the easiest way to achieve appropriate parental behavior in males would be to organize and activate existing neuroendocrine pathways leading to maternal behavior (Rilling \& Mascaro, 2017). It is very likely that the essential hormonal stimuli required for parental behavior are shared by males and females, and the same hormones act at the same neural sites to facilitate the expression of the same repertoire of parental behaviors in both sexes. Obvious sex differences in these behaviors should descend from differential gene expression rather than structural dimorphism (Kelley, 1988). Current evidence suggests that mammalian paternal care-giving behaviors rely upon the same neural pathways, as those supporting maternal behavior, making use of the same neural sub- 
strates and hormonal systems (Feldman et al., 2019). It is well known, in particular, that the medial preoptic area (mPOA) of the hypothalamus as well as the bed nucleus of stria terminalis (BNST) play the key role in stimulation and regulation of maternal care: these brain regions contain cells expressing various neurotransmitters and neuropeptides, and the diverse projections of these cells connect to multiple neural targets in the mammalian parenting network to support maternal behavior; by contrast, anterior hypothalamic nucleus, ventromedial hypothalamic nucleus, and periaqueductal gray participate in the inhibiting mechanisms of neural regulation of maternal behavior (Numan \& Insel, 2003; Numan \& Stolzenberg, 2009). It is hypothesized that there are the same facilitating and inhibiting mechanisms in the neural regulation of paternal behavior (Romero-Morales et al., 2018b).

However, despite evidence for similarity in the neurobiology of maternal and paternal behaviors in rodents, paternal behavior also has its own dedicated neural circuitry in some species. For example, in the study of two Peromyscus species - P. polionotus and $P$. maniculatus - that exhibit differences in parental behavior, twelve genomic regions that control parental care were identified. Eight of these regions were found to be sex-specific, suggesting that parenting behavior evolved along independent lines in females and males (Bendesky et al., 2017). Moreover, some authors suppose that the hypothesis of homology between paternal and maternal behavior has not yet been adequately tested, and it is possible that different neuroendocrine circuits could lead to the same behavior in males and females (De Vries \& Boyle, 1998; Wynne-Edwards \& Timonin, 2007).

As for the neuroendocrine basis of male parental care in rodents, current evidence suggests that males in biparental species undergo systematic changes in hormonal and neuropeptide signaling during the transition to fatherhood, in association with pair formation, mating, cohabitation with a pregnant female, and/or exposure to infants. Some of these changes differ across species, and their functional significance, including potential effects on paternal behavior, is generally unknown. Several hormones, including steroids (estradiol, progesterone, testosterone) and peptides (prolactin, vasopressin, oxytocin), as well as many exteroceptive stimuli are involved in the onset, the maintenance, or both the onset and the maintenance of parental behavior, including direct paternal care. The understanding of the neural substrates of parental care has particularly benefited from what was known about the neural control of sexual behaviors. Specifically, sex differences in parental care in laboratory rats and mice can be influenced in both sexes, at least to some degree, by perinatal manipulation of androgen exposure (Lonstein \& De Vries, 2000). Although the circuit underlying parental care seems to be similar in male and female rodents, its regulation is sex-specific and depends on both experience and, in male rodents, exposure to the pregnant and lactating dam.

\section{Testosterone interference}

Circulating testosterone concentrations are typically reduced in fathers and have been shown convincingly to influence the expression of paternal behavior; however, effects may differ both within and among species (Saltzman et al., 2017).

Specifically, testosterone was found to decrease in new fathers of California mice (Gubernick \& Nelson, 1989); however, castration reduces and testosterone or estrogen replacement restores parental behavior in this species (Trainor \& Marler 2001, 2002). The stimulatory effect of testosterone in California mice is thought to be mediated by aromatization of testosterone to estrogen in the brain (Trainor \& Marler, 2002).

Similar results, when castration reduces and testosterone replacement restores parental behavior, were shown in virgin male Mongolian gerbils housed in same-sex groups (Martınez et al., 2015); however, virgin male gerbils housed with a lactating female showed the opposite pattern (Clark \& Galef, 1999). One of recent studies (Martínez et al., 2019) shows that paternal behavior in Mongolian gerbils is associated with high testosterone concentrations in blood samples. On the other hand, high testosterone concentrations during in utero development was found to interfere with male parental behavior, resulting in a trade-off between mating effort (high testosterone) and parental effort (low testosterone) in this gerbil species (Clark \& Galef, 1999, 2000). Another study showed that Mongolian gerbil testosterone concentrations have been correlated with the rate of paternal care, and that testosterone levels do not decrease when the males give paternal care (Luis et al., 2010). Studies of prairie voles have likewise yielded mixed results: castration either reduced (Wang \& De Vries, 1993; Lonstein et al., 2002) or did not alter (Lonstein \& De Vries, 1999) responses to pups in males. Hence, more studies are needed to determine if and how testosterone is involved in the regulation of paternal behavior in Mongolian gerbils and prairie voles.

The hypothesis about inverse association, or tradeoff, between circulating testosterone concentrations and paternal care (Ketterson \& Nolan, 1992) has not been supported by other experimental studies. In particular, castration did not reduce paternal responsiveness in biparental P. campbelli (Hume \& Wynne-Edwards, 2005; Romero-Morales et al., 2018a). Both expectant and new fathers of this species had higher testosterone concentrations than they have had before pairing (Reburn \& Wynne-Edwards, 1999; Schum \& WynneEdwards, 2005). Moreover, testosterone concentration was found to be more responsive to the birth in uniparental $P$. sungorus than in biparental $P$. campbelli (Schum \& Wynne-Edwards, 2005). In the mandarin vole (Lasiopodomys mandarinus), males that successfully raised their offspring had higher content of gonadal testosterone than males that were unable to take parental care of the offspring because of their death (Gromov \& Voznesenskaya, 2013). It was also shown that serum concentration of testosterone as well as testosterone content in the testes of bank vole Clethrionomys glareolus males 
exhibiting parental responsiveness were higher than in the males inclined to infanticide. Increased testosterone content in the testes and blood serum was also found in red-backed vole Clethrionomys rutilus males that had contact with pups (Gromov \& Osadchuk, 2015). Thus, the effect of testosterone on paternal responsiveness is not universal and, moreover, species-specific: in some rodents, testosterone inversely correlates with paternal behavior while no effect or positive correlation has been found in other species.

\section{Progesterone interference}

Progesterone is rarely measured in male rodents. In uniparental male laboratory mice, interference with the progesterone receptors was found to increase paternal behavior and decrease infanticide behavior, whereas increasing progesterone has the opposite effect (Schneider et al., 2003). This finding shows that experimental manipulation of progesterone may alter paternal behavior in non-paternal species of rodents.

As for biparental rodents, California mouse males were shown to have lower progesterone concentrations as they became fathers (Trainor et al., 2003; Perea-Rodriguez et al., 2015). However, the pattern was found to be opposite in dwarf hamsters ( $P$. campbelli and $P$. sungorus). Progesterone concentrations in naïve males were the same in both two species, but biparental P. campbelli had a significant progesterone increase from before to after the birth of pups, whereas uniparental P. sungorus did not (Schum \& Wynne-Edwards, 2005). Hence, although progesterone dynamics differentiate the two species of dwarf hamsters as their males become fathers, the result of the study are opposite to predictions. In other words, it is unlikely that there is a simple inverse association between progesterone and paternal behavior in $P$. campbelli.

In general, much more experimental data are required for better understanding the association of progesterone with male parental care in different rodent species.

\section{Estradiol facilitation}

One of hormones facilitating the onset and the maintenance of male parental behavior could be estradiol. For example, in male laboratory rats, parental responsiveness was experimentally induced by estradiol implantation (Rosenblatt \& Ceus, 1998). Estradiol can also promote paternal behavior in California mice through the aromatization of peripheral testosterone into estradiol (Trainor \& Marler, 2002). The actions of estradiol in the males involve the mPOA, which expresses aromatase enzyme (for the conversion of androgens to estradiol, $\mathrm{E}_{2}$ ) as well as estrogen receptor (Rosenblatt \& Ceus, 1998; Trainor et al., 2003; Cushing \& Wynne-Edwards, 2006). Recently, paternal behavior in Mongolian gerbils was found to be associated with the presence of estrogen receptor $\alpha$ (ER $\alpha$ ) in the mPOA, the olfactory bulbs, and the medial nucleus of the amygdala (MeA) (Martínez et al., 2019). Moreover, the neural regulation of paternal behavior in this gerbil species is thought to underlie positive and negative mechanisms as occurs in maternal behavior (Romero-Morales et al., 2018b).

Similarly to the finding in California mice, males of dwarf hamsters (Phodopus spp.) were also found to have peripheral estradiol concentrations as high as reproductive females (Schum \& Wynne-Edwards, 2005). High estradiol is suggested to be a predisposing adaptation to facilitate the onset of paternal behavior in $P$. campbelli (Wynne-Edwards \& Reburn, 2000). However, neither estradiol dynamics nor pharmacological manipulation of estradiol support a causal link between estradiol and paternal behavior in dwarf hamsters: in contrast to predictions based on the results in females, estradiol in uniparental $P$. sungorus males increases before the birth and falls across the birth, whereas estradiol concentration in biparental $P$. campbelli males does not change (Schum \& Wynne-Edwards, 2005). Castration removes the primary source of both estradiol and testosterone in P. campbelli males (Hume \& Wynne-Edwards, 2005), but paternal behavior towards an experimentally displaced pup was not reduced (Hume \& Wynne-Edwards, 2005). There is also no evidence that local aromatization of androgen to estradiol within the brain is involved in paternal behavior of dwarf hamsters (Hume \& Wynne-Edwards, 2006). Reduced estradiol did not reduce paternal behavior even when prior experience with the birth or the pups was eliminated (Hume \& Wynne-Edwards, 2005, 2006). However, when these males were treated with $\mathrm{E}_{2}$ and the concentrations of this hormone increased significantly, they became paternal (Romero-Morales et al., 2018a). This finding contrasts with the conclusion of Hume and Wynne-Edwards (2005) and suggests that an increase in $\mathrm{E}_{2}$ levels shifted infanticidal behavior to paternal behavior in P. campbelli. Besides, it was found that experimental increase in the expression of estrogen receptor $\alpha(E R \alpha)$ in the medial amygdala inhibited parental behavior in adult males of the prairie vole (Cushing et al., 2008), while increasing ER $\alpha$ expression in the BNST had no effect (Lei et al., 2010).

The results of these studies suggest that unlike the onset of paternal behavior, the maintenance of this behavior is not dependent on steroid hormones, as in maternal behavior. Thus, further investigations are needed for better understanding the role of estrogens in the activation and the maintenance of paternal behavior in different rodent species.

Neuropeptides: prolactin, oxytocin, and vasopressin

Paternal behavior, similar to maternal behavior, was found to be associated with changes in the levels of prolactin, oxytocin, and vasopressin. The extent of these changes parallels the amount of direct paternal care (Feldman et al., 2019).

The anterior pituitary hormone prolactin has been referred to as "the hormone of paternity" (Schradin \& Anzenberger, 1999), as circulating or excreted levels are elevated in fathers of numerous biparental species 
and often correlate with males' expression of paternal behavior (Saltzman \& Ziegler, 2014; Hashemian et al., 2016).

In male rodents, there is good support for a positive association between concentrations of prolactin in peripheral circulation and the expression of appropriate paternal care (Wynne-Edwards, 2001). In male laboratory rats, prolactin promotes, and a dopamine agonist inhibits, 'pup-contact-induced' paternal behavior (Sakaguchi et al., 1996). Similar patterns are seen in several biparental rodent species. For example, in California mice, both new fathers and new mothers have elevated prolactin concentrations relative to non-fathers (Gubernick \& Nelson, 1989). In Mongolian gerbils, paired males have higher prolactin concentrations than unmated males (Brown et al., 1995). Paternal Djungarian hamsters have an increase in prolactin concentration during the late afternoon of the day before their female partner gives birth that is not seen in uniparental P. sungorus males (Reburn \& WynneEdwards, 1999). The increase in males is synchronous with an increase in female prolactin concentration (Edwards et al., 1995). Thus, prolactin may facilitate the initiation of infant care in some rodent species.

It was found, however, that striped mice provided extensive paternal care but did not experience an increase in prolactin associated with fatherhood; nevertheless, males had higher prolactin levels during the breeding season than during the non-breeding season (Schradin \& Pillay, 2004). Besides, in the experiments with Djungarian hamsters, it was shown that dopamine agonist treatment before and after the birth reduced prolactin concentration, but did not impair paternal responsiveness (Brooks et al., 2005). Thus, in spite of some evidence documenting a positive association between prolactin and paternal behavior, the experiments that pharmacologically reduce prolactin in a naturally paternal animal model, like Djungarian hamsters, do not support a causal pathway. Similarly, circulating prolactin does not appear to mediate sex difference in parental behavior of prairie voles (Lonstein \& de Vries, 2000). There is suggestion that prolactin secretion in polygynous rodent species might be regulated by environmental stimuli, whereas social stimuli might be important for socially monogamous species (Schradin \& Pillay, 2004). Therefore, further investigations are needed to highlight the role of prolactin in the activation and the maintenance of paternal behavior in different rodent species.

Oxytocin and vasopressin are well-known neuropeptide hormones involved in social interactions (Young, 1999) and likely to be involved in parental behavior (Francis et al., 2002; Bridges, 2015; Kenkel et al., 2017). Oxytocin is also known as a potent prolactin-releasing factor (Liu \& Ben-Jonathan, 1994). However, little is known about effects of oxytocin on rodent paternal care. In experiments with prairie voles, paternal behavior of adult virgin males was found to be inhibited by combined intracerebroventricular treatment with an arginine vasopressin (AVP) receptor antagonist and an oxytocin receptor antagonist, but not by either antagonist alone
(Bales et al., 2004). On the other hand, when male prairie voles received a neonatal injection of an oxytocin antagonist, these males displayed less parental behavior at the age of 21 days compared to males that were handled without injection (Bales et al., 2011).

It is also found that hypothalamic oxytocin gene expression does not increase in male prairie voles or montane voles (Microtus montanus) that become fathers (Wang et al., 2000), and peripheral oxytocin concentrations in California mice are elevated after mating, but low and unchanged while the pups are young and dependent (Gubernick et al., 1995). More recently, males of California mice participating in paternal care-giving also showed lower levels of oxitocin than non-breeding males (Perea-Rodriguez et al., 2015). Treatment with a different oxytocin receptor antagonist inhibited parental behavior in adult male prairie voles in a dose-dependent manner (Kenkel et al., 2017). In mandarin voles, fathers had a significantly higher serum concentration of oxytocin than virgin males; the levels of the oxytocin receptor in the mPOA of fathers were also significantly higher than in virgin males (Yuan et al., 2019). These results support the suggestion that oxytocin could be involved in stimulation of paternal behavior or, at least, in the adaptation to fatherhood in some rodent species, but further investigations are needed to highlight the role of oxytocin in the activation and the maintenance of paternal care in rodents.

Recent findings suggest that arginine vasopressin (AVP) could be also important for paternal behavior. Specifically, injection of AVP into the lateral septum (LS) in prairie voles enhanced paternal responsiveness toward young pups (Wang et al., 1994, 1999), and both male and female prairie voles had increased vasopressin gene expression after the young were born (Wang et $a l ., 2000)$. Like oxytocin, vasopressin can also release prolactin (Shin, 1996). Expression of AVP receptor (V1a) increased social affiliation both in prairie voles and laboratory mice (Young et al., 1999; Lim et al., 2004). Central infusion of AVP receptor antagonists had the opposite effect in prairie voles (Wang et al., 1994, 1999) and even in promiscuous meadow voles (Parker \& Lee, 2001b). On the other hand, castration of male prairie voles virtually eliminated AVP-immunoreactivity (AVP-ir) in the LS and lateral habenular nucleus (LHN), but did not alter paternal behavior, indicating that AVP signaling in these areas is not essential for expression of paternal care (Lonstein \& De Vries, 1999). Monogamous male Californian mice showed more AVP-ir staining in BNST than the polygamous Peromyscus leucopus, as well as more AVP receptors in LS (Bester-Meredith et $a l ., 1999)$. These results are congruent with finding that circulating vasopressin is correlated with paternal behavior of $P$. californicus (Bester-Meredith \& Marler, 2003).

Both within and among rodent species, paternal behavior was found to correlate with patterns of AVP-ir and AVP-binding, particularly in LS and other parts of the extended amygdala (Bales \& Saltzman, 2016). For example, in California mice, high care male offspring had significantly more AVP-ir cells within the BNST than low 
care offspring (Yohn et al., 2017). However, according to other study, California mouse males participating in paternal care-giving showed lower levels of AVP V1a receptor mRNA expression than shown in non-breeding males (Perea-Rodriguez et al., 2015). On the other hand, in male prairie voles, variation in the length of microsatellite DNA in the regulatory region of the avprla gene encoding AVP V1a receptor (V1aR) underlies differences in $\mathrm{V} 1 \mathrm{aR}$ neural expression and is correlated with significant differences in partner preference and paternal behavior: males possessing longer avpr1a microsatellite alleles spend more time with their female social partner, sire offspring with fewer females and provide more paternal care relative to males with shorter avprla microsatellite alleles (Castelli et al., 2011).

In addition, there is evidence indicating that the AVP is involved in regulation of indirect paternal behavior. Specifically, Bendesky et al. (2017) identify the AVP gene as a likely contributing factor to the evolution of inter-specific differences in parental behavior related to nest building in two Peromyscus species - P. polionotus and $P$. maniculatus. The expression of AVP itself was found to differ between $P$. polionotus and $P$. maniculatus, and this difference may explain the association between nest building and the gene locus on chromosome 4 .

Thus, oxytocin and vasopressin are obviously associated with paternal behavior, but most closely functionally linked to social affiliation and pair bonding (Carter et al., 1992; Bamshad et al., 1994; Insel et al., 1994; Insel \& Hulihan, 1995; Wang et al., 1999; Numan \& Insel, 2003). At a proximate level, the existing evidence implies a common physiological substrate for both paternal behavior and pair-bonds. New research focusing on involvement of neuropeptides in the initiation and the maintenance of male parental care may help us understand inter-specific variation in paternal responsiveness of rodents

Relatively little is known about the effects of parity on paternal behavior in rodents. Prior parenting experience was shown to have no effect on paternal behavior in prairie voles (Wang \& Novak, 1994; Kenkel et al., 2019). However, fathers of this species, compared to virgin males, exhibited higher levels of oxytocin-immunoreactivity in the paraventricular hypothalamus; on the other hand, the fathers had less oxytocin in the BNST (Kenkel et al., 2014). Contrary to the results obtained for the prairie vole, observations of breeding pairs of the social vole revealed that experienced fathers were significantly more active in pup grooming than new fathers (Gromov, 2011a). Similarly, in the mandarin vole, experienced fathers displayed more active paternal behaviors such as licking, retrieval, and nest building than new fathers; besides, new fathers had significantly higher levels of oxytocin receptors, but lower levels of dopamine- 2 type receptors in the nucleus accumbens compared to experienced fathers (Wang et al., 2018). The oxytocin receptor (OTR) levels in the MeA of new fathers were found to decrease with the age of pups; in contrast, OTR levels of experienced fathers significantly increased with the age of pups (Wang et al., 2018). In striped mice, experienced males had higher prolactin levels than inexperienced males (Schradin \& Pillay, 2004). These data illustrate that fathering experience could increase the active components of parental care and alter the expression levels of receptors of some neuropeptides. One can conclude that paternal experiences do facilitate paternal behavior in some rodent species, but other cues play a role as well.

In summary, while gonadal hormones such as testosterone, estrogen, and progesterone, as well as hypothalamic neuropeptides such as oxytocin and vasopressin, and the pituitary hormone prolactin, are implicated in the activation of paternal behavior, there are significant gaps in our knowledge of their actions, as well as pronounced differences between species. Hence, future studies should focus on the neuroendocrine mechanism that underlies paternal behavior in rodents. These studies should examine similar outcome measures in multiple species, including both biparental species and closely related uniparental species. Careful phylogenetic analyses of the neuroendocrine systems presumably important to male parenting, as well as their patterns of gene expression, will also be important in establishing the next generation of hypotheses regarding the neuroendocrine regulation of male parenting behavior.

\section{Epigenetic 'programming' of paternal} behaviors

Over the last decade, experimental studies clearly demonstrated that animal genomes are regulated to a large extent as a result of input from environmental events and experiences, which cause short- and longterm modifications in epigenetic markings of DNA and histones (Jensen, 2013). Recent evidence shows that such epigenetic modifications can affect the behavior of rodents, and acquired behavior alterations can be inherited either through the germline or through reoccurring environmental conditions (Reik, 2001; Rakyan \& Whitelaw, 2003; Rakyan \& Beck, 2006; Skinner et al., 2008; Curley et al., 2011; Geoghegan \& Spencer, 2012; Szyf, 2015). In other words, the environment experienced by parents can affect offspring phenotype, including their behavior.

Epigenetic inheritance, i.e., the inheritance of information beyond the DNA sequence in forms such as cytosine methylation and histone acetylation, is the likeliest mechanism by which ancestral environments could influence offspring; microRNA (mRNA, short endogenous noncoding RNA) is also involved in the posttranscriptional regulation of gene expression (Turner et al., 2015; Mashoodh \& Champagne, 2019). Epigenetic inheritance means that genetically identical organisms exhibit a range of phenotypes that are heritable despite not resulting from variation in DNA sequence. The epigenetic inheritance of acquired characters is also called the epigenetic (re)programming of phenotypic differences (Reik, 2001; McGowan et al., 2008; Skinner et al., 2008; Jablonka \& Raz, 2009). The epigenetic programming is known to result in alteration of gene expression levels in the brain related to stimulation and regulation of different 
behaviors, including paternal care (Carone et al., 2010; Song et al., 2010; Jia et al., 2011; Rando, 2012; Saltzman et al., 2017). Moreover, parental care itself is revealed to be one of important factors resulting in epigenetic programming of the offspring behavior (Champagne, 2008, 2011; Champagne \& Curley, 2009; Champagne \& Rissman, 2011; Rando, 2012). The impact of paternal care on the neural systems regulating social behavior in offspring can lead to multigenerational continuity in paternal behavior, similar to the mother-daughter transmission of maternal behavior in rodents (Champagne, 2008).

\section{Effects of sensitization}

In rodents, interactions with younger siblings or unrelated pups, either during the juvenile period or in adulthood, may contribute to both intra- and inter-individual differences in paternal responsiveness (so called effect of sensitization, when parental behavior is induced through prolong contact with infant stimuli, Brown \& Moger, 1983; Dewsbury, 1985; Walsh et al., 1996). For instance, virgin prairie vole males that have lived with younger siblings are significantly more likely to behave paternally to an unfamiliar pup than those that have no experience with younger siblings, although most males in both conditions behave paternally (Roberts et al., 1999). Similarly, virgin males of California mice that have lived with their parents and younger siblings show higher levels of paternal care toward an unrelated pup, compared to virgin males that have lived with only their parents and a littermate but no younger siblings, or with only a littermate (Gubernick \& Laskin, 1994).

Species also differ in whether repeated exposure to pups during adulthood facilitates the onset of paternal care. In the study of California mice (Horrell et al., 2017), adult virgin males with no previous exposure to pups were found to engage in less paternal behavior than new fathers, and virgins' paternal responsiveness was increased by repeated, brief (20-min) exposure to pups. In adult virgin male mandarin voles, even a single, 10-min exposure to an unrelated pup increased paternal responsiveness to an unrelated pup a week later (Song et al., 2010). Paternal responsiveness of some captive bank vole males could be also explained by the effect of sensitization (Gromov \& Osadchuk, 2015). In contrast, repeated 10-min exposure to a pup did not reliably alter paternal behavior in adult virgin male Djungarian hamsters, even after four exposures (Vella et al., 2005). Similar to dwarf hamsters, adult virgin male prairie voles showed no change in parental behavior after three consecutive 20-min exposures to pups over several days (Kenkel et al., 2013). Therefore, the effect of repeated exposure to pups seems to be species-specific.

It is known that the mPOA is implicated in the process of sensitization (Rosenblatt et al., 1996; Sturgis \& Bridges, 1997). Experiments with California mice (Lee \& Brown, 2002) have shown that lesions to the mPOA disrupted paternal behavior, and increased neuronal activity in the mPOA has been observed following pup exposure (de
Jong et al., 2009). Besides, other brain sites, such as the $\mathrm{MeA}$, the basolateral amygdala, the BNST, the ventral pallidum and the LS, have also been shown to be crucial to the emergence of paternal behavior (Kirkpatrick et al., 1994; Lee \& Brown, 2002; de Jong et al., 2009; Akther et al., 2014). For instance, in California mice, immunoreactivity for immediate early genes such as fos (a marker of neuronal activation) increased in the BNST of new fathers, suggested altered neural transmission in this area (de Jong et al., 2009), and lesions to the basolateral amygdala impaired paternal behavior (Lee \& Brown, 2002). In prairie voles, exposure to pups increased fos expression in the mPOA, the MeA, the LS, the paraventricular nucleus of the thalamus, and the BNST (Kirkpatrick et al., 1994). Lesions to the MeA in this species decreased paternal behavior (Kirkpatrick et al., 1994), and lesions to the ventral pallidum increased latency to retrieve and groom pups (Akther et al., 2014). Similar to lactating females, specific pools of the mPOA galanin-expressing neurons in the male brain project to inhibitory periaqueductal grey neurons to promote pup grooming, to the ventral tegmentum area neurons to increase approach behavior, and to the MeA neurons to suppress competing social stimuli to help the males focus on pups. All these regions and neural circuits are suggested to integrate to form the rodent subcortical paternal network (Feldman et al., 2019).

Experiments with C57BL/6J mice have shown that experience with infants elicits long-lasting increases in parental care via epigenetic modifications (Bonthuis et al., 2011; Stolzenberg et al., 2012). Epigenetic mechanisms mediating the long-term effects of parental care provide multigenerational continuity in parental behavior, including paternal responsiveness (Champagne \& Curley, 2009).

By the way, facultative paternal behavior has been reported for some non-paternal rodent species under unfavorable breeding conditions (see, for instance, Barash, 1975; Mihok, 1979; Wynne-Edwards, 1995), as well as in captivity (McGuire \& Novak, 1984, 1986; Dewsbury, 1985; Storey \& Snow, 1987; Xia \& Millar, 1988; Storey et al., 1994; Wolff, 2003; Gromov \& Osadchuk, 2015). These findings may indicate that the pup care reported for some rodent species in small cages is a laboratory artifact. Alternatively, males of these species have the potential to display paternal behavior, and may do so under certain conditions (Dewsbery, 1985; Gromov, 2011). This unusual paternal responsiveness could be easily explained by the effect of sensitization as a result of contact with pups in laboratory cages. For example, in male meadow voles, decreased aggression and facilitation of paternal responsiveness occurred most reliably after extensive exposure to pups (Storey \& Joyce, 1995). The paternal neural activation was revealed in $P$. maniculatus males as a result of experience with pups, and enhanced $\mathrm{mPOA}$ activation was associated with this paternal response (Lambert et al., 2013).

Both copulation and postcopulatory cohabitation with pregnant females were shown to reduce infanticide and enhance paternal responsiveness in male CS1 mice, and the effectiveness of copulation in this process depends 
on the number of occasions that males have previously encountered infants (Elwood, 1986). Similarly, copulation and cohabitation suppress pup-directed aggression in previously aggressive meadow vole males, but these males exhibited paternal behavior only following $24 \mathrm{~h}$ of postpartum exposure to pups (Parker \& Lee, 2001a). These behavioral data suggest that copulation and cohabitation with a female are sufficient to suppress pup-directed aggression in non-paternal rodents, but these social stimuli are ineffective regulators of paternal behavior onset, and postpartum interaction with pups seems to be the most effective social experience for making males paternal.

\section{Other epigenetic effects}

In an epigenetic approach to behavioral development, ontogeny is viewed as a series of interactions between an organism and its environment (Lehrman, 1970; Johnston, 1987). As for paternal care and factors (both internal and external) affecting its development and variability, it needs to note that behavioral responses to pups may differ markedly among individual sexually naïve males as well as among individual fathers within a species. Although this variability is likely to arise in part from genetic influences, early-life experience can also contribute to long-term behavioral differences among males. Two important sources of inter-individual variation in paternal responsiveness could be identified: intrauterine position during gestation and parental care received during the pre-weaning period.

It is known that circulating hormones during gestation can influence later behavior. For example, individuals gestating between two males (2M) experience higher androgen levels than those between two females $(2 \mathrm{~F})$, and these intrauterine position effects have consequences in adulthood. Specifically, in Mongolian gerbils (Clark et al., 1998), intrauterine position was found to influence both males' behavioral responses to pups in adulthood and potential hormonal mediators of paternal behavior. Males that gestated between two sisters ( $2 \mathrm{~F}$ males) had significantly more contact with pups than males that gestated between two brothers (2M males). Moreover, $2 \mathrm{M}$ males had higher circulating testosterone levels in adulthood than $2 \mathrm{~F}$ males (Clark et al., 1992). In house mice, $2 \mathrm{M}$ males had decreased sexual activity, but were more aggressive and more paternal than $2 \mathrm{~F}$ males (Mateo, 2007).Due to studies in other rodents, it was revealed that differences in males' intrauterine position are associated with differences in exposure to androgens and estrogens during gestation (Vom Saal et al., 1983; Pei et al., 2006), as well as with differences in expression of androgen receptors and a steroidogenic enzyme, 5a-reductase, in peripheral reproductive organs (Nonneman et al., 1992; Ryan \& Vandenbergh, 2002). Therefore, intrauterine position likely affects males' parental behavior in adulthood by modulating exposure to steroid hormones during both early development and adulthood.

After parturition, young directly experience their physical and social environments, and social stimulation from parents can have profound effects on behavioral development. For example, in laboratory rats, variation in maternal behaviors, such as nursing postures and rates of licking and grooming of pups, influences the development of serial traits in their young, as offspring of high licker/groomers are less fearful and have smaller stress responses than those of low licker/groomers (Weaver et al., 2004; Meaney \& Szyf, 2005; Weaver, 2007; Meaney et al., 2007). Cross-fostering studies indicated that these effects on offspring are due to postnatal maternal handling rather than inherited traits. Daughters of high-licking and grooming mothers became high-licking and grooming mothers themselves, thus transmitting variation in parental behavior non-genetically across generations (Liu et al., 1997; Francis et al., 1999; Meaney, 2001). The neurobiological studies have revealed that maternal care (the extent of maternal grooming) affects DNA methylation and gene expression in the brain of the offspring (Fish et al., 2004). Long-term changes in offspring behavior are associated with expression of estrogen receptor alpha $(E R \alpha)$ in the $\mathrm{mPOA}$ of the hypothalamus, rendering animals with higher receptor levels more sensitive to estrogen (Champagne et al., 2003). Differences in ER $\alpha$ receptor expression between offspring of low-licking and grooming mothers and high-licking and grooming mothers are attributable to methylation of the ER $\alpha$ promoter region (Champagne et al., 2006). These epigenetic modifications to gene expression are persistent, predicting how a female will behave towards her future offspring.

The same epigenetic effect of paternal grooming could be expected in male rodents. Brown (1993) has particularly noted that the type and frequency of parental behavior received by males during infancy may influence their display of paternal behavior in adulthood. This statement is supported by the results of recent studies. In particular, a cross-fostering study with California mice, in which offspring were reared by a foster father engaging in relatively higher or lower levels of paternal behavior than engaged by the biological father, indicated that the quality and quantity of paternal care expressed depend on the males' own neonatal and adult experience of paternal care (Bester-Meredith \& Marler, 2003). Like in laboratory rats, in the California mouse, it is possible that a similar mechanism of stimulation of parental behavior is involved because testosterone promotes grooming behavior in males via conversion to estradiol $\mathrm{E}_{2}$ (Trainor \& Marler, 2001). California mouse fathers were found to have significantly more aromatase activity in the mPOA compared with mated non-fathers, indicating that with fatherhood comes a regional increase in conversion of testosterone to $\mathrm{E}_{2}$ (Gleason \& Marler, 2013).

Other experimental studies also show that the expression of paternal care in biparental rodent species is dependent on the quality and/or quantity of care that fathers received from their own parents (Gromov, 2009, 2011a; Braun \& Champagne, 2014; Bales \& Saltzman, 2016): specifically, males that were reared uniparentally (i.e., without their fathers present) subsequently perform less paternal care toward their own offspring than do males reared biparentally (i.e., by both parents). In particular, 
male Mongolian gerbils reared without father display lower paternal responsiveness, indicated by reduced nest attendance and grooming of their pups (Gromov, 2009). In mandarin voles, paternal deprivation also reduced paternal behavior in male offspring (Jia et al., 2011; Yu et al., 2015; Wang et al., 2014, 2015). As in Mongolian gerbils and mandarin voles, prairie vole fathers raised by only their mothers performed less paternal behavior toward their own offspring than did fathers that have been raised by both parents (Ahern et al., 2011). The study on California mice has also shown that the amount of licking and grooming received by pups was significantly decreased in father-absent families (Bredy et al., 2004). One of recent studies revealed that male California mice raised by fathers which paternal care was experimentally reduced were engaged in less huddling and grooming of their offspring (Gleason \& Marler, 2013). It means that a significant reduction in paternal care influences the development of offspring paternal behavior. Importantly, pups reared by single mothers receive less total parental care (especially, because of a lack of paternal pup grooming) and are faced with a deficiency of thermoregulation in the nest than those reared by both parents (Gromov, 2009 , 2011a). These early postnatal conditions associated with paternal deprivation may negatively affect subsequent behavioral development of young in biparental rodent species. In other words, the postnatal social environment experienced by offspring shapes the systems that support paternal behavior in adulthood.

Recent research suggests that grooming of pups is an important contributing factor to development of paternal care and epigenetic (re)programming of male parental behavior in rodents (Gromov, 2009, 2011a, 2011b, 2013, 2018). Some experimental studies show that, due to pup grooming, it is possible to stimulate paternal responsiveness even in males of species with uniparental care. For example, in a cross-fostering study, male meadow voles raised by prairie vole foster parents received higher levels of parental care, especially grooming, during pre-weaning development and subsequently performed some paternal behaviors toward their own offspring, compared to male meadow voles raised by conspecific foster parents and showed no paternal care (McGuire, 1988).

Similar to cross-generational transmission of maternal behavior (Champagne, 2008), this paternal transmission is likely to involve altered gene regulation in neural systems associated with social and reproductive behavioral phenotypes, resulting in a later recapitulation of the social context of early development. Likely targets include the dopaminergic, neuropeptide (oxytocin and vasopressin) and neuroendocrine systems that are known to be impacted by paternal deprivation (Bester-Meredith \& Marler, 2003; Brown et al., 2013; Cao et al., 2014; Gos et al., 2014). As for the role of specific molecular mechanisms such as DNA methylation, histone modifications or the effects of mRNA, as well as the roles of the enzymes that regulate these factors, in this transmission, it requires, of course, further investigation.

Epigenetic effects related to paternal care in rodents have been also supported by the results of some other studies. For example, in experiments with California mice (Gleason \& Marler, 2013), paternal behavior performed by castrated and sham-operated males and, subsequently, by their sons was estimated. Castration or sham surgeries were performed on adult males to generate mice that huddled and groomed their offspring at quantitatively different levels. When tested in their home cage with one of their pups, castrated fathers took significantly longer than intact fathers to approach and begin caring for their pups, and spent significantly less time huddling and grooming their pups. These differences were repeated in the subsequent generation: gonadally intact sons of castrated fathers spent significantly less time huddling and grooming their pups, and performed significantly more retrievals of pups, than sons of intact fathers. Although neural and endocrine measures were not characterized in the offspring in this study, it was shown in previous studies that sons of castrated males of California mice had lower AVP-immunoreactivity in the dorsal region of the BNST compared to sons of intact males, as well as higher AVP-immunoreactivity in the paraventricular nucleus; thus, AVP may be a critical neurochemical underlying non-genomic transfer of behavioral patterns (Marler et al., 2003; Frazier et al., 2006). Therefore, individual differences in paternal behavior may be transmitted across generations, potentially mediated by changes in AVP signaling within the brain due to epigenetic mechanisms.

Comparison of paternal behavior in prairie voles that had received different patterns of care from their own parents was carried out in the study of Perkeybile et al. (2013). Offspring of "high-contact" parents experienced high total levels of contact with their parents but relatively low levels of contact with their fathers specifically, compared to offspring of "low-contact" parents. When tested with an unfamiliar pup shortly after weaning, sons of high-contact pairs engaged in more non-huddling contact with the pup than sons of low-contact pairs. Cross-fostering studies demonstrated that this effect was mediated primarily by experiential, rather than genomic, transmission of behavior, as juvenile males' behavioral responses to pups correlated with several components of parental behavior that they had received from their foster parents (Perkeybile et al., 2015). In addition, binding of AVP and oxytocin in the BNST of juvenile males correlated significantly or marginally, respectively, with several aspects of parental care received, as well as with AVP and oxytocin binding in their biological parents.

Taken together, all these studies demonstrate that the quality and/or quantity of parental care that males receive during early postnatal development, especially due to tactile stimulation from their parents (Gromov, 2011a, 2011b, 2013), influence their behavioral responses to pups in adulthood, and that the differences in parenting style can be transmitted to the next generation. They also indicate that these developmental effects on paternal behavior are associated with, and perhaps mediated by, changes in oxytocin and AVP signaling within the brain. 


\section{Conclusion}

Paternal care is an evolutionary mystery. Analysis of various circumstances in which paternal care has been observed provided no clear conclusions concerning its evolutionary scenarios. The fitness benefits of providing paternal care are not clearly understood as well. Male parental care in rodents is undoubtedly associated with social monogamy, or more correctly, with a family-group lifestyle. However, no convincing hypotheses accounted for the evolution of social monogamy in rodents has been proposed. Similarly, current evolutionary models do not convincingly explain emergence of male parental care among different representatives of order Rodentia.

The onset, activation and maintenance of paternal care are governed by complex interactions in neuroendocrine systems that change during ontogeny. The neural adaptations that take place in male parents are less uniform and hormone-dependent than those that take place in female parents. Moreover, these changes are shaped, to a great extent, by active care-giving, exposure to the pregnant or lactating female, and the presence or absence of specific infant stimuli. The male's prior social experiences, the type of parental care he received, and his experience with pups may all influence his initial responsiveness to pups. Depending on the species, different components of male experience as well as different exogenous cues are likely to be involved in the organization and activation of paternal behavior. These exogenous stimuli, including maternal response, paternal effects, and infant stimuli, must then activate the central nervous system to evoke the needed learning and behavior.

Several hormones, including steroids (testosterone, estradiol, progesterone) and neuropeptides (prolactin, vasopressin, and oxytocin), are involved in the onset, the maintenance, or both the onset and the maintenance of parental behavior, including direct paternal care. The effect of testosterone is not universal and, moreover, species-specific: in some species, testosterone inversely correlates with paternal behavior while no effect or positive correlation has been found in other species. The role of progesterone in the initiation and maintenance of male parental care is not yet clear. The limited results of neurobiological studies to date provide some contradictions, and therefore further investigations are needed for a better understanding of the role of estrogens as well as neuropeptides in activation and maintenance of rodent paternal behavior.

Recent research shows that paternal environmental conditions can affect the phenotypes of offspring. Extensive genetic and molecular evidence supports a role for interconnected epigenetic information carriers such as RNAs, chromatin state, and DNA modifications in transgenerational inheritance of epivariable phenotypes. In most cases of transgenerational environmental inheritance, it is not yet clear how the relevant information is carried from males to their offspring, but epigenetic information is likely to be relevant for most such cases. Future studies should focus on the epigenetic mechanisms that underlie paternal behavior in rodents.
In general, much remains to be learned about paternal care in rodents, and promising insight will likely come from broader studies using a multi-faceted proximate/ ultimate approach involving within and between species comparisons in free-living rodent species. Field and experimental studies of rodents exhibiting paternal care as well as appropriate genetic studies will be a valuable addition to understanding how paternal care has arisen in various radiations of rodent taxonomy, given the broad expression of paternal care among rodents and the distribution of the phenomenon among many distantly related taxa.

\section{References}

Ahern T.H., Hammock E.A. \& Young L.J. 2011. Parental division of labor, coordination, and the effects of family structure on parenting in monogamous prairie voles (Microtus ochrogaster) // Developmental Psychobiology. Vol.53. P.118-31.

Akther S., Fakhrul A.A.K.M. \& Higashida H. 2014. Effects of electrical lesions of the medial preoptic area and the ventral pallidum on mate-dependent paternal behavior in mice // Neuroscience Letters. Vol.570. P.21-24.

Bales K.L. \& Saltzman W. 2016. Fathering in rodents: Neurobiological substrates and consequences for offspring // Hormones and Behavior. Vol.77. P.249-59.

Bales K.L., Kim A.J., Lewis-Reese A.D. \& Carter C.S. 2004. Both oxytocin and vasopressin may influence alloparental behavior in male prairie voles // Hormones and Behavior. Vol.45. P.354-361.

Bales K.L., Boone E., Epperson P., Hoffman G. \& Carter C.S. 2011. Are behavioral effects of early experience mediated by oxytocin? // Frontiers of Psychiatry. Vol.2. P.24.

Bamshad M., Novak M.A. \& de Vries G.J. 1994. Cohabitation alters vasopressin innervation and paternal behavior in prairie voles (Microtus ochrogaster) // Physiology \& Behavior. Vol.56. P.751-758.

Barash D.P. 1975. Ecology of paternal behavior in the hoary marmot (Marmota caligata): An evolutionary interpretation // Journal of Mammalogy. Vol.56. P.613-618.

Bendesky A., Kwon Y.-M., Lassance J.-M., Lewarch C.L., Yao S., Peterson B.K., He M.X., Dulac C. \& Hoekstra H.E. 2017. The genetic basis of parental care evolution in monogamous mice // Nature. Vol.544. P.434-439.

Bester-Meredith J.K. \& Marler C.A. 2003. Vasopressin and the transmission of paternal behavior across generations in mated, cross-fostered Peromyscus mice // Behavioral Neuroscience. Vol.117. P.455-463.

Bester-Meredith J.K., Young L.J. \& Marler C.A. 1999. Species differences in paternal behavior and aggression in Peromyscus and their associations with vasopressin immunoreactivity and receptors // Hormones and Behavior. Vol.36. P.25-38.

Bonthuis P.J., Patteson J.K. \& Rissman E.F. 2011. Acquisition of sexual receptivity: roles of chromatin acetylation, estrogen receptor-alpha, and ovarian hormones // Endocrinology. Vol.152. P.3172-3181.

Brady C.A. \& Svendsen G.E. 1981. Social behaviour in a family of beaver, Castor canadensis // Biology of Behaviour. Vol.6. P.99-114. 
Braun K. \& Champagne F.A. 2014. Paternal influence son offspring development: behavioural and epigenetic pathways // Journal of Neuroendocrinology. Vol.26. P.697-706.

Bredy T.W., Lee A.W., Meaney M.J. \& Brown R.E. 2004 Effect of neonatal handling and paternal care on offspring cognitive development in the monogamous California mouse (Peromyscus californicus) // Hormones and Behavior. Vol.46. P.30-38.

Bridges R.S. 2015. Neuroendocrine regulation of maternal behavior // Frontiers of Neuroendocrinology. Vol.36. P.178-196.

Brooks P.L., Vella E.T. \& Wynne-Edwards K.E. 2005. Dopamine agonist treatment before and after the birth reduces prolactin concentration but does not impair paternal responsiveness in Djungarian hamsters, Phodopus campbelli // Hormones and Behavior. Vol.47. P.358-366.

Brown R.E. 1993. Hormonal and experimental factors influencing parental behavior in male rodents: An integrative approach // Behavioural Processes. Vol.30. P.1-28.

Brown R.E. \& Moger W.H. 1983. Hormonal correlates of parental behavior in male rats // Hormones and Behavior. Vol.17. P.356-365.

Brown R.E., Murdoch T., Murphy P.R. \& Moger W.H. 1995. Hormonal responses of male gerbils to stimuli from their mate and pups // Hormones and Behavior. Vol.29. P.474-491.

Brown K., Seidel K., Holetschka R., Groeger N. \& Poeggel G. 2013. Paternal deprivation alters the development of catecholaminergic innervation in the prefrontal cortex and related limbic brain regions // Brain Structure and Functions. Vol.218. P.859-872.

Cao Y., Wu R., Tai F., Zhang X., Yu P., An X., Qiao X. \& Hao P. 2014. Neonatal paternal deprivation impairs social recognition and alters levels of oxytocin and estrogen receptor $\alpha \mathrm{mPRA}$ expression in the MeA and NAcc, and serum oxytocin in mandarin voles // Hormones and Behavior. Vol.65. P.57-65.

Carone B.R., Fauquier L., Habib N., Shea J.M., Hart C.E., Li R., Bock C., Li C., Gu H. \& Zamore P.D. 2010. Paternally induced transgenerational environmental reprogramming of metabolic gene expression in mammals // Cell. Vol.143. P.1084-1096.

Carter C.S., Williams J.R., Witt D.M. \& Insel T.R. 1992. Oxytocin and social bonding // Annals New York Academy of Science. Vol.652. P.204-211.

Castelli F.R., Kelley R.A., Keane B. \& Solomon N.G. 2011. Female prairie voles show social and sexual preferences for males with longer avprla microsatellite alleles // Animal Behaviour. Vol.82. P.1117-1126.

Champagne F.A. 2008. Epigenetic mechanisms and the transgenerational effects of maternal care // Frontiers of Neuroendocrinology. Vol.29. P.386-397.

Champagne F.A. 2011. Maternal imprints and the origins of variation // Hormones and Behavior. Vol.60. P.4-11.

Champagne F.A. \& Curley J.P. 2009. Epigenetic mechanisms mediating the long-term effects of maternal care on development// Neuroscience and Biobehavioral Reviews. Vol.33. P.593-600.

Champagne F.A. \& Rissman E.F. 2011. Behavioral epigenetics: A new frontier in the study of hormones and behavior // Hormones and Behavior. Vol.59. P.277-278.
Champagne F.A., Weaver I.C.G., Diorio J., Sharma S. \& Meaney M J. 2003. Natural variations in maternal care are associated with estrogen receptor alpha expression and estrogen sensitivity in the medial preoptic area // Endocrinology. Vol.144. P.4720-4724.

Champagne F.A., Weaver I.C., Diorio J., Dymov S., Szyf M. \& Meaney M.J. 2006. Maternal care associated with methylation of the estrogen receptor-alphalb promoter and estrogen receptor-alpha expression in the medial preoptic area of female offspring// Endocrinology. Vol.147. P.2909-2915.

Clark M.M. \& Galef B.G. 1999. A testosterone-mediated tradeoff between parental and sexual effort in male Mongolian gerbils (Meriones unguiculatus) // Journal of Comparative Psychology. Vol.113. P.388-395.

Clark M.M. \& Galef B.G. 2000. Why some male Mongolian gerbils may help at the nest: testosterone, asexuality and alloparenting // Animal Behaviour. Vol.59. P.801-806.

Clark M.M., vom Saal F.S. \& Galef B.J. Jr. 1992. Intrauterine positions and testosterone levels of adult male gerbils are correlated // Physiology \& Behavior. Vol.51. P.957-960.

Clark M.M., Vonk J.M. \& Galef B.G. Jr. 1998. Intrauterine position, parenting, and nest-site attachment in male Mongolian gerbils // Developmental Psychobiology. Vol.32. P.177-181.

Clutton-Brock T.H. 1989. Mammalian mating systems // Proceedings of the Royal Society of London, Series B. Vol.236. P.339-372.

Clutton-Brock T.H. 1991. The evolution of parental care. Princeton: Princeton Univ. Press. 365 p.

Curley J.P., Mashoodh R. \& Champagne F.A. 2011. Epigenetics and the origins of paternal effects // Hormones and Behavior. Vol.59. P.306-314.

Cushing B.S. \& Wynne-Edwards K.E. 2006. Estrogen receptoralpha distribution in male rodents is associated with social organization // Journal of Comparative Neurology. Vol.494. P.595-605.

Cushing B.S., Perry A., Musatov S., Ogawa S. \& Papademetriou E. 2008. Estrogen receptors in the medial amygdala inhibit the expression of male prosocial behavior // Journal of Neuroscience. Vol.28. P.10399-10403.

De Jong T.R., Chauke M., Harris B.N. \& Saltznan W. 2009. From here to paternity: Neural correlates of the onset of paternal behavior in California mice (Peromyscus californicus) // Hormones and Behavior. Vol.56. P.220-231.

De Vries G.J. \& Boyle P.A. 1998. Double duty for sex differences in the brain // Behavioural Brain Research. Vol.92. P.205-213.

Dewsbury D.A. 1985. Paternal behavior in rodents // American Zoologist. Vol.25. P.841-852.

Edwards H.E., Reburn C.J. \& Wynne-Edwards K.E. 1995. Daily patterns of pituitary prolactin secretion and their role in regulating maternal serum progesterone concentrations across pregnancy in the Djungarian hamster (Phodopus campbelli)// Biology of Reproduction. Vol.52. P.814-823.

Eisenberg J.F. 1965. The social organization of mammals // Handbook of Zoology. Vol.8. P.1-191.

Elwood R.W. 1977. Changes in the responses of male and female gerbils (Meriones unguiculatus) towards test pups during the pregnancy of the female // Animal Behaviour. Vol.25. P.46-51. 
Elwood R.W. 1983. Paternal care in rodents // Elwood R.W. (ed.). Parental Behaviour of Rodents. New York: John Wiley \& Sons. P.441-455.

Elwood R.W. 1986. What makes male mice paternal? // Behavioral and Neural Biology. Vol.46. P.54-63.

Emlen S.T. 1982. The evolution of helping. I. An ecological constraints model // American Naturalist. Vol.119. P.29-39.

Emlen S.T. \& Oring L.W. 1977. Ecology, sexual selection, and the evolution of mating systems // Science. Vol.197. P.215-223.

Feldman R., Braun K. \& Champagne F.A. 2019. The neural mechanisms and consequences of paternal caregiving // Nature Reviews: Neuroscience. Vol.20. P.205-224.

Fish E.W., Shahrokh D., Bagot R., Caldji C., Bredy T., Szyf M. \& Meaney M.J. 2004. Epigenetic programming of stress responses through variations in maternal care // Annals New York Academy of Science. Vol.1036. P.167-180.

Francis D., Diorio. J., Liu D. \& Meany M.J. 1999. Nongenomic transmission across generations of maternal behavior and stress responses in the rat// Science. Vol.286. P.1155-1158.

Francis D.D., Young L.J., Meaney M.J. \& Insel T.R. 2002. Naturally occurring differences in maternal care are associated with the expression of oxytocin and vasopressin (V1a) receptors: gender differences // Journal of Neuroendocrinology. Vol.14. P.349-353.

Geoghegan J.L. \& Spencer H.G. 2012. Population-epigenetic models of selection // Theoretical Population Biology. Vol.81. P.232-242.

Getz L.L., McGuire B., Pizzuto T., Hofmann J.E. \& Frase B. 1993. Social organization of the prairie vole (Microtus ochrogaster) // Journal of Mammalogy. Vol.74. P.44-58.

Gleason E.D. \& Marler C.A. 2013. Non-genomic transmission of paternal behaviour between fathers and sons in the monogamous and biparental California mouse // Proceedings of Biology Sciences. Vol.280. P.20130824.

Gos T., Schulkin J., Gos A., Bock J., Poeggel G. \& Braun K. 2014. Paternal deprivation affects the functional maturation of corticotrophin-releasing hormone $(\mathrm{CRH})$ and calbindinD28k-expressing neurons in the bed nucleus of the stria terminalis (BNST) of the biparental Octodon degus // Brain Structure and Functions. Vol.219. P.1983-1990.

Gromov V.S. 2008. [The spatial-and-ethological population structure in rodents.] Moscow: KMK Sci. Press. 582 p. [In Russian]

Gromov V.S. 2009. Interactions of partners in family pairs, care of the offspring, and the role of tactile stimulation in formation of parental behavior of the Mongolian gerbil (Meriones unguiculatus) under laboratory conditions // Biology Bulletin. Vol.36. No.5. P.479-488.

Gromov V.S. 2011a. Parental care, tactile stimulation and sociality evolution in rodents: Behavioural, physiological and developmental aspects. LAP LAMBERT Academic Publ. 104 p.

Gromov V.S. 2011b. Biparental care, tactile stimulation, and evolution of sociality in rodents // Journal of Evolutionary Biology Research. Vol.3. P.33-43.

Gromov V.S. 2013. The early experience of tactile stimulation and its behavioral consequences related to socialization in mammals // Andersen E.L. \& Thomas S. (eds.). Socialization: Theories, Processes and Impact. New York: Nova Science Publ. P.1-28.
Gromov V.S. 2014. Complicated social structure and the evolution of sociality in rodents: Cooperation as the main promoting factor. // Watson P. (ed.). Social Behavior: Evolutionary Pathways, Environmental Influences and Impairments. New York: Nova Science Publ. P.71-119.

Gromov V.S. 2017. The spatial-and-ethological population structure, cooperation, and the evolution of sociality in rodents // Behaviour. Vol.154. P.609-649.

Gromov V.S. 2018. The evolution of sociality in rodents: Environments and selective forces promoting grouping. LAP LAMBERT Academic Publ. 163 p.

Gromov V.S. \& Osadchuk L.V. 2015. Parental care and testosterone secretion in forest rodent males: sensitization and androgenic stimulation of parental behavior // Biology Bulletin. Vol.42. No.4. P.354-360.

Gromov V.S. \& Voznesenskaya V.V. 2013. Care of young, aggressiveness, and secretion of testosterone in male rodents: a correlation analysis // Biology Bulletin. Vol.40. No.5. P.463-470.

Gubernick D.J. \& Alberts J.R. 1989. Postpartum maintenance of paternal behaviour in the biparental California mouse, Peromyscus californicus // Animal Behaviour. Vol.37. P.656-664.

Gubernick D.J. \& Laskin B. 1994. Mechanisms influencing sibling care in the monogamous biparental California mouse, Peromyscus californicus // Animal Behaviour. Vol.48. P.1235-1237.

Gubernick D.J. \& Nelson R.J. 1989. Prolactin and paternal behavior in the biparental California mouse, Peromyscus californicus // Hormones and Behavior. Vol.23. P.203-210.

Gubernick D.J. \& Teferi T. 2000. Adaptive significance of male parental care in a monogamous mammal // Proceedings of the Royal Society of London, Series B. Vol.267. P.147-150.

Gubernick D.J., Wright S.L. \& Brown R.E. 1993. The significance of father's presence for offspring survival in the monogamous California mouse, Peromyscus californicus // Animal Behaviour. Vol.46. P.539-546.

Gubernick D.J., Winslow J.T., Jensen P., Jeanotte L. \& Bowen J. 1995. Oxytocin changes in males over the reproductive cycle in the monogamous, biparental California mouse, Peromyscus californicus // Hormones and Behavior. Vol.29. P.59-73.

Hartung T.G. \& Dewsbury D.A. 1979. Paternal behavior in six species of muroid rodents // Behavioral and Neural Biology. Vol.26. P.466-478.

Hashemian F., Shafigh F. \& Roohi E. 2016. Regulatory role of prolactin in paternal behavior in male parents: a narrative review // Journal of Postgraduated Medicine. Vol.62. P.182-187.

Helmeke C., Seidel K., Poeggel G., Bredy T.W., Abraham A. \& Braun K. 2009. Paternal deprivation during infancy results in dendrite-and time-specific changes of dendritic development and spine formation in the orbitofrontal cortex of the biparental rodent Octodon degus // Neuroscience. Vol.163. P.790-798.

Hodgdon H.E., Lancia R.A., 1983. Behavior of the North American beaver, Castor canadensis // Acta Zoologica Fennici. Vol.174. P.99-103.

Holmes W.G. 1984. The ecological basis of monogamy in Alaskan hoary marmots // Murie J.O. \& Michener J.R. (eds.). The biology of ground-dwelling squirrels. Lincoln: Univ. Nebraska Press. P.250-274. 
Horner B.E. \& Taylor J.M. 1968. Growth and reproductive behavior in the southern grasshopper mouse // Journal of Mammalogy. Vol.49. P.644-660.

Horrell N.D., Perea-Rodriguez J.P., Harris B.N. \& Saltzman W. 2017. Effects of repeated pup exposure on behavioral, neural, and adrenocortical responses to pups in male California mice (Peromyscus californicus) // Hormones and Behavior. Vol.90. P.56-63.

Huber S., Millesi E. \& Dittami J.P. 2002. Paternal effort and its relation to mating success in the European ground squirrel// Animal Behaviour. Vol.63. P.157-164.

Hume J.M. \& Wynne-Edwards K.E. 2005. Castration reduces male testosterone, estradiol, and territorial aggression, but not paternal behavior in biparental dwarf hamsters (Phodopus campbelli) // Hormones and Behavior. Vol.48. P.303-310.

Hume J.M. \& Wynne-Edwards K.E., 2006. Paternal responsiveness in biparental dwarf hamsters (Phodopus campbelli) does not require estradiol // Hormones and Behavior. Vol.49. P.538-544.

Insel T.R. \& Hulihan T.J. 1995. A gender-specific mechanism for pair bonding: Oxytocin and partner preference formation in monogamous voles // Behavioral Neuroscience. Vol.109. P.782-789

Insel T.R., Wang Z.X. \& Ferris C.F. 1994. Patterns of brain vasopressin receptor distribution associated with social organization in microtine rodents // Journal of Neuroscience. Vol.14. P.5381-5392.

Jablonka E. \& Raz G. 2009. Transgenerational epigenetic inheritance: prevalence, mechanisms, and implications for the study of heredity and evolution // Quarterly Review of Biology. Vol.84. P.131-176.

Jakubowski M. \& Terkel J. 1985. Transition from pup killing to parental behavior in male and virgin female albino rats // Physiology \& Behavior. Vol.34. P.683-686.

Jensen P. 2013. Transgenerational epigenetic effects on animal behaviour // Progress in Biophysics and Molecular Biology. Vol.113. P.447-454.

Jia R., Tai F., An S. \& Zhang X. 2011. Neonatal paternal deprivation or early deprivation reduces adult parental behavior and central estrogen receptor $\alpha$ expression in mandarin voles (Microtus mandarinus) // Behavioural Brain Research. Vol.224. P.279-289.

Johnston T.D. 1987. The persistence of dichotomies in the study of behavioral development // Developmental Review. Vol.7. P.149-182.

Kalcounis-Rüppel M.C. \& Ribble D.O. 2007. A phylogenetic analysis of the breeding systems of neotomine-peromyscine rodents // Wolff J.O. \& Sherman P.W. (eds.). Rodent Societies - An Ecological \& Evolutionary Perspective. Chicago: Univ. Chicago Press. P.68-85.

Kelley D.B. 1988. Sexually dimorphic behaviors // Annual Review of Neuroscience. Vol.11. P.225-251.

Kenkel W.M., Paredes J., Lewis G.F., Yee J.R., PournajafiNazarloo H., Grippo A.J., Porges S.W. \& Carter C.S. 2013. Autonomic substrates of the response to pups in male prairie voles // PLoS One. Vol.8. P.69965.

Kenkel W.M., Suboc G. \& Carter C.S. 2014. Autonomic, behavioral and neuroendocrine correlates of paternal behavior in male prairie voles // Physiology \& Behavior. Vol.128. P.252-259.
Kenkel W.M., Perkeybile A.M. \& Carter C.S. 2017. The neurobiological causes and effects of alloparenting // Developmental Neurobiology. Vol.77. P.214-232.

Kenkel W.M., Perkeybile A.M., Yee J.R. \& Carter C.S. 2019. Rewritable fidelity: How repeated pairings and age influence subsequent pair-bond formation in male prairie voles // Hormones and Behavior. Vol.113. P.47-54.

Ketterson E.D. \& Nolan V., Jr. 1992. Hormones and life histories: An integrative approach // American Naturalist. Vol.140 (Suppl.). P.S33-S62.

Kirkpatrick B., Kim J.W. \& Insel T.R. 1994. Limbic system fos expression associated with paternal behavior // Brain Research. Vol.658. P.112-118.

Kleiman D.G. 1977. Monogamy in mammals // Quarterly Review of Biology. Vol.52. P.39-69.

Kleiman D.G. \& Malcolm J.R. 1981. The evolution of male parental investment // Gubernick D.J. \& Klopfer P.H. (eds.). Parental care in mammals. New York: Plenum Press. P.347-387.

Komers P.E. \& Brotherton P.N.M. 1997. Female space use is a best predictor of monogamy in mammals // Proceedings of the Royal Society of London, Series B. Vol.264. P.1261-1270.

Kurland J.A. \& Gaulin S.J.C. 1984. The evolution of male parental investment: effects of genetic relatedness and feeding ecology on the allocation of reproductive effort // Taub D.W. (ed.). Primate paternalism. New York: Van Nostrand Reinhold. P.259-308.

Lambert K.G., Franssen C.L., Hampton J.E., Rzucidlo A.M., Hyer M.M., True M., Kaufman C. \& Bardi M. 2013. Modeling paternal attentiveness: Distressed pups evoke differential neurobiological and behavioral responses in paternal and non-paternal mice // Neuroscience. Vol.234. P.1-12.

Lambin N. \& Krebs C.J. 1991. Spatial organization and mating system of Microtus townsendii // Behavioral Ecology and Sociobiology. Vol.28. P.353-363.

Lee A.W. \& Brown R.E. 2002. Medial preoptic lesions disrupt parental behavior in both male and female California mice (Peromyscus californicus) // Behavioral Neuroscience. Vol.116. P.968-975.

Lehrman D.S. 1970. Semantic and conceptual issues in the nature-nurture problem // Aronson L.R., Tobach E., Lehrman D.S. \& Rosenblatt J.S. (eds.). Development and evolution of behavior. San Francisco: Freeman W.H. P.17-52.

Lei K., Cushing B.S., Musatov S., Ogawa S. \& Kramer K.M. 2010. Estrogen receptor- $\alpha$ in the bed nucleus of the stria terminalis regulates social affiliation in male prairie voles (Microtus ochrogaster) // PLos One. Vol.5. P.8931.

Lim M.M., Murphy A.Z. \& Young L.J. 2004. Ventral striatopallidal oxytocin and vasopressin V1a receptors in the monogamous prairie vole (Microtus ochrogaster) // Journal of Comparative Neurology. Vol.468. P.555-570.

Liu J.W. \& Ben-Jonathan N. 1994. Prolactin-releasing activity of neurohypophysial hormones: structure-function relationship // Endocrinology. Vol.134. P.114-118.

Liu D., Diorio J., Tannenbaum B., Caldji C., Francis D., Freedman A. \& Shanna S. 1997. Maternal care, hippocampal glucocorticoid receptors, and hypothalamicpituitary-adrenal responses to stress // Science. Vol.277. P.1659-1662. 
Lonstein J.S. \& De Vries G.J. 1999. Sex differences in the parental behaviour of adult virgin prairie voles: independence from gonadal hormones and vasopressin // Journal of Neuroendocrinology. Vol.11. P.441-449.

Lonstein J.S. \& De Vries G.J. 2000. Sex differences in the parental behavior of rodents // Neuroscience and Biobehavioral Reviews. Vol.24. P.669-686.

Lonstein J.S., Rood B.D. \& De Vries G.J. 2002. Parental responsiveness is feminized after neonatal castration in virgin male prairie voles, but is not masculinized by perinatal testosterone in virgin females // Hormones and Behavior. Vol.41. P.80-87.

Luis J., Vázquez-Gaytán B., Martínez-Torres M., Carmona A., Ramos-Blancas G. \& Ortíz G. 2010. Neither testosterone levels nor aggression decrease when the male Mongolian gerbil (Meriones unguiculatus) displays paternal behavior // Hormones and Behavior. Vol.57. P.271-275.

Lukas D. \& Clutton-Brock T.H. 2013. The evolution of social monogamy in mammals // Science. Vol.341. P.526-530.

Maher C.R. \& Burger J.R. 2016. Diversity of social behavior in caviomorph rodents // Ebensperger L.A. \& Hayes L.D. (eds.). Sociobiology of caviomorph rodents: an integrative approach. Chichester: John Wiley \& Sons. P.28-58.

Marinelli L. \& Messier F. 1993. Space use and the social system of muskrat (Ondatra zibethicus) // Canadian Journal of Zoology. Vol.71. P.869-875.

Marinelli L. \& Messier F. 1995. Parental care strategies among muskrats in a female-biased population // Canadian Journal of Zoology. Vol.73. P.1503-1510.

Marler C.A., Bester-Meredith J.K. \& Trainor B.C. 2003. Paternal behavior and aggression: Endocrine mechanisms and nongenomic transmission of behavior // Advances in the Study of Behavior. Vol.32. P.263-323.

Martınez A., Ramos G., Martınez-Torres M., Nicolas L., Carmona A., Cardenas M. \& Luis J. 2015. Paternal behavior in the Mongolian gerbil (Meriones unguiculatus): estrogenic and androgenic regulation // Hormones and Behavior. Vol.71. P.91-95.

MartínezA., Arteaga-Silva M., Bonilla-Jaime H., Cárdenas M. \& Luis J. 2019. Paternal behavior in the Mongolian gerbil, and its regulation by social factors, T, ER $\alpha$, and AR // Physiology \& Behavior. V.199. P.351-358.

Mashoodh R. \& Champagne F.A. 2019. Paternal epigenetic inheritance// Transgenerational Epigenetics. 2nd ed.P.107-133.

Mateo J.M. 2007. Ontogeny of adaptive behaviors // Wolff J.O. \& Sherman P.W. (eds.). Rodent Societies - An Ecological \& Evolutionary Perspective. Chicago: Univ. Chicago Press. P.195-206.

Maynard-Smith J. 1977. Parental investment: a prospective analysis // Animal Behaviour. Vol.25. P.1-9.

Maynard-Smith J. 1982. Evolution and the Theory of Games. Cambridge: Cambridge University Press. 265 p.

McCarty R. \& Southwick C.H. 1977. Patterns of parental care in two cricetid rodents, Onychomys torridus and Peromyscus leucopus // Animal Behaviour. Vol.25. P.945-948.

McGowan P.O., Meaney M.J. \& Szyf M. 2008. Diet and the epigenetic (re)programming of phenotypic differences in behavior // Brain Research. Vol.1237. P.12-24.

McGuire B. 1988. Effects of cross-fostering on parental behavior of meadow voles (Microtus pennsylvanicus) // Journal of Mammalogy. Vol.69. P.332-341.
McGuire B. 2003. Paternal care and its effect on maternal behavior and pup survival and development in prairie voles (Microtus ochrogaster) // Exploring Animal Behavior in Laboratory and Field. P.167-176.

McGuire B. \& Bemis W.E. 2007. Parental care // Wolff J.O. \& Sherman P.W. (eds.). Rodent Societies - An Ecological \& Evolutionary Perspective. Chicago: Univ. Chicago Press. P.231-242.

McGuire B. \& Novak M. 1984. A comparison of maternal behaviour in the meadow vole (Mictotus pennsylvanicus), prairie vole (M. ochrogaster) and pine vole (M. pinetorum) // Animal Behaviour. Vol.32. P.1132-1141.

McGuire B. \& Novak M. 1986. Parental care and its relation to social organization in the montane vole // Journal of Mammalogy. Vol.67. P.305-311.

McGuire B., Henyey E., McCue E. \& Bemis W.E. 2003. Parental behavior at parturition in prairie voles (Microtus ochrogaster) // Journal of Mammalogy. Vol.84. P.513-523.

Meaney M.J. 2001. Maternal care, gene expression, and the transmission of individual differences in stress reactivity across generations // Annual Review of Neuroscience. Vol.24. P.1161-1192.

Meaney M.J. \& Szyf M. 2005. Maternal care as a model for experience-dependent chromatin plasticity? // Trends in Neuroscience. Vol.28. P.456-463.

Meaney M.J., Szyf M. \& Seckl J.R. 2007. Epigenetic mechanisms of perinatal programming of hypothalamicpituitary-adrenal function and health // Trends in Molecular Medicine. Vol.13. P.269-277.

Mihok S. 1979. Behavioral structure and demography of subarctic Clethrionomys gapperi and Peromyscus maniculatus // Canadian Journal of Zoology. Vol.57. P.1520-1535.

Nonneman D.J., Ganjam V.K., Welshons W.V. \& vom Saal F.S. 1992. Intrauterine position effects on steroid metabolism and steroid receptors of reproductive organs in male mice // Biology of Reproduction. Vol.47. P.723-729.

Numan M. \& Insel T. 2003. The Neurobiology of Parental Behavior. New York: Springer. 418 p.

Numan M. \& Stolzenberg D.S. 2009. Medial preoptic area interactions with dopamine neural systems in the control of the onset and maintenance of maternal behavior in rats // Frontiers in Neuroendocrinology. Vol.30. P.46-64.

Orians G.H. 1969. On the evolution of mating systems in birds and mammals // The American Naturalist. Vol.103. P.589-604.

Parker K.J. \& Lee T.M. 2001a. Social and environmental factors influence the suppression of pup-directed aggression and development of paternal behavior in captive meadow voles (Microtus pennsylvanicus) // Journal of Comparative Psychology. Vol.115. P.331-336.

Parker K.J. \& Lee T.M. 2001b. Central vasopressin administration regulates the onset of facultative paternal behavior in Microtus pennsylvanicus (meadow voles) // Hormones and Behavior. Vol.39. P.285-294.

Patris B. \& Baudoin C. 2000. A comparative study of parental care between two rodent species: implications for the mating system of the mound-building mouse Mus spicilegus // Behavioural Processes. Vol.51. P.35-43.

PayneR.B. \& Payne L.L. 1993. Breeding dispersal in Indigo buntings: circumstances and consequences for breeding success and population structure // Condor. Vol.95. P.1-24. 
Pei M., Matsuda K.-I., Sakamoto H. \& Kawata M. 2006. Intrauterine proximity to male fetuses affects the morphology of the sexually dimorphic nucleus of the preoptic area in the adult rat brain // European Journal of Neuroscience. Vol.23. P.1234-1240.

Perea-Rodriguez J.P., Takahashi E.Y., Amador T.M., Hao R.C., Saltzman W. \& Trainor B.C. 2015. Effects of reproductive experience on central expression of progesterone, estrogen $\alpha$, oxytocin and vasopressin receptor mRNA in male California mice (Peromyscus californicus) // Journal of Neuroendocrinology. Vol.27. P.245-252.

PerkeybileA.M., Griffin L.L. \& Bales K.L. 2013. Natural variation in early parental care correlates with social behaviors in adolescent prairie voles (Microtus ochrogaster) // Frontiers in Behavioral Neuroscience. Vol.7:21.

Perkeybile A.M., Delaney-Busch N., Hartman S., Grimm K.J. \& Bales K.L. 2015. Intergenerational transmission of alloparental behavior and oxytocin and vasoapressin receptor distribution in the prairie vole // Frontiers in Behavioral Neuroscience. Vol.9:191.

Perrigo G., Belvin L. \& vom Saal F.S. 1991. Individual variation in the neural timing of infanticide and parental behavior in male house mice // Physiology \& Behavior. Vol.50. P.287-296.

Porter R.H., Cavallaro S.A. \& Moore J.D. 1980. Developmental parameters on mother-offsping interactions in Acomys cahirinus // Zeitschrift für Tierpsychologie. Bd.53. S.153-170.

Rakyan V.K. \& Beck S. 2006. Epigenetic variation and inheritance in mammals // Current Opinion in General Development. Vol.16. P.573-577.

Rakyan V. \& Whitelaw E. 2003. Transgenerational epigenetic inheritance // Current Biology. Vol.13. P.6.

Rando O.J. 2012. Daddy issues: Paternal effects on phenotype // Cell. Vol.151. P.702-708.

Reburn C.J. \& Wynne-Edwards K.E. 1999. Hormonal changes in males of a naturally biparental and a uniparental mammal // Hormones and Behavior. Vol.35. P.163-176.

Reik W. 2001. Epigenetic reprogramming in mammalian development // Science. Vol.293. P.1089-1093.

Requena G.S. \& Alonzo S.H. 2017. Sperm competition games when males invest in paternal care // Proceedings of Biology Sciences. Vol.284:20171266.

Reynolds J.D., Goodwin N.B. \& Freckleton R.P. 2002. Evolutionary transitions in parental care and live bearing in vertebrates // Philosophical Transactions Royal Society of London, Series B. Vol.357. P.269-281.

Ribble D.O. 2003. The evolution of social and reproductive monogamy in Peromyscus, evidence from Peromyscus californicus (the California mouse) // Reichard U. \& Boesh C. (eds.). Monogamy: Mating strategies and partnership in birds, humans, and other mammals. Cambridge: Cambridge Univ. Press. P.81-92.

Ribble D.O. \& Salvioni M. 1990. Social organization and nest co-occupancy in Peromyscus californicus, a monogamous rodent//Behavioral Ecology and Sociobiology. Vol.26. P.9-15.

Ridley P. 1978. Paternal care // Animal Behaviour. Vol.26. P.904-932.

Rilling J.K. \& Mascaro J.S. 2017. The neurobiology of fatherhood // Current Opinion in Psychology. Vol.15. P.26-32.
Roberts R.L., Williams J.R., Wang A.K. \& Carter C.S. 1998. Cooperative breeding and monogamy in prairie voles: Influence of the sire and geographic variation // Animal Behaviour. Vol.55. P.1131-1140.

Roberts R.L., Miller A.K., Taymans S.E. \& Carter C.S. 1999. Role of social and endocrine factors in alloparental behavior of prairie voles (Microtus ochrogaster) // Canadian Journal of Zoology. Vol.76. P.1862-1868.

Romero-Morales L., Martínez-Torres M., Cárdenas M., Álvarez C., Carmona A., Cedillo B., Loya-Zurita E. \& Luis J. 2018a. An increase in estradiol facilitates the onset of paternal behavior in the dwarf hamster (Phodopus campbelli) // Hormones and Behavior. Vol.99. P.35-40.

Romero-Morales L., Cárdenas M., Martínez-Torres M., García-Saucedo B., Carmona A. \& Luis J. 2018b. Neuronal activation associated with paternal and aversive interactions toward pups in the Mongolian gerbils (Meriones unguiculatus) // Hormones and Behavior. Vol.105. P.47-57.

Rosenbaum S. \& Getter L.T. 2018. With a little help from her friends (and family) part II: non-maternal care-giving behavior and physiology in mammals // Physiology \& Behavior. Vol.193. P.12-24.

Rosenblatt J.S. \& Ceus K. 1998. Estrogen implants in the medial preoptic area stimulate maternal behavior in male rats // Hormones and Behavior. Vol.33. P.23-30.

Rosenblatt J.S., Hazelwood S. \& Poole J. 1996. Maternal behavior in male rats: effects of medial preoptic area lesions and presence of maternal aggression // Hormones and Behavior. Vol.30. P.201-215.

Royle N.J., Russel A.F. \& Wilson A.J. 2014. The evolution of flexible parenting // Science. Vol.345. P.776-781.

Ryan B.C. \& Vandenbergh J.G. 2002. Intrauterine position effects // Neuroscience and Biobehavioral Reviews. Vol.26. P.665.

Rymer T. \& Pillay N. 2011. The influence of the early rearing environment on the development of paternal care in African striped mice // Ethology. Vol.117. P.284-293.

Rymer T. \& Pillay N. 2018. An integrated understanding of paternal care in mammals: Lessons from the rodents // Journal of Zoology. Vol.306. No.2. P.69-76.

Sakaguchi K., Tanaka M., Ohkubo T., Dohura K., Fujikawa T., Sudo S. \& Nakashima K. 1996. Induction of brain prolactin receptor long-form mRNA expression and maternal behavior in pup-contacted male rats: promotion by prolactin administration and suppression by female contact // Neuroendocrinology. Vol.63. P.559-568.

Saltzman W. \& Ziegler T.E. 2014. Functional significance of hormonal changes in mammalian fathers // Journal of Neuroendocrinology. Vol.26. P.685-96.

Saltzman W., Harris B.N., De Jong T.R., Perea-Rodriguez J.P., Horrell N.D., Zhao M. \& Andrew J.R. 2017. Paternal care in biparental rodents: intra- and inter-individual variation // Integrative and Comparative Biology. Vol.57. P.589-602.

Schneider J.S., Stone M.K., Wynne-Edwards K.E., Horton T.H., Lydon J.P., O'Malley B. \& Levine J.E. 2003. Progesterone receptors mediate male aggression towards infants // Proceedings of the National Academy of Sciences of USA. Vol.100. P.2951-2956.

Schradin C. \& Anzenberger G. 1999. Prolactin, the hormone of paternity // New Physiological Sciences. Vol.14. P.223-231. 
Schradin C. \& Pillay N. 2004. Prolactin levels in paternal striped mouse (Rhabdomys pumilio) fathers // Physiology \& Behavior. Vol.81. P.43-50.

Schubert M., Pillay N. \& Schradin C. 2009. Parental and alloparental care in a polygynous mammal // Journal of Mammalogy. Vol.90. P.724-731.

Schum J.E. \& Wynne-Edwards K.E. 2005. Estradiol, progesterone and testosterone in paternal and non-paternal hamsters (Phodopus) becoming fathers: conflict with hypothesized roles. Hormones and Behavior. Vol.47. P.410-418.

Shen S.F., Emlen S.T., Koenig W.D. \& Rubenstein D.R. 2017. The ecology of cooperative breeding behaviour // Ecology Letters. Vol.20. P.708-720.

Shin S.H. 1996. Vasopressin has a direct effect on prolactin release in male rats // Neuroendocrinology. Vol.34. P.55-58.

Skinner M., Anway M., Savenkova M. \& Gore A. 2008. Transgenerational epigenetic programming of the brain transcriptome and anxiety behavior // PLoS ONE. Vol.3. P.3745.

SlobodchikoffC.N. 1984. Resources and the evolution of social behavior // Price P.W., Slobodchikoff C.N. \& Gaud W.S. (eds.). A New Ecology: Novel Approaches to Interactive Systems. New York: John Wiley \& Sons. P.227-251.

Solomon N.G., Keane B., Knoch L.R. \& Hogan P.J. 2004. Multiple paternity in socially monogamous prairie voles (Microtus ochrogaster) // Canadian Journal of Zoology. Vol.82. P.1667-1671.

Sommer S. 1997. Monogamy in Hypogeomys antimena, an endemic rodent of the deciduous dry forest in western Madagascar // Journal of Zoology. Vol.241. P.301-314.

Song Z., Tai F., Yu C., Wu R., Zhang X., Broders H., He F. \& Guo R. 2010. Sexual or paternal experiences alter alloparental behavior and the central expression of Era and OT in male mandarin voles (Microtus mandarinus) // Behavioural Brain Research. Vol.214. P.290-300.

Soroker V. \& Terkel J. 1988. Changes in incidence of infanticidal and parental responses during the reproductive cycle in male and female wild mice Mus musculus // Animal Behaviour. Vol.36. P.1275-1281.

Stockley P. \& Hobson L. 2016. Paternal care and litter size coevolution in mammals // Proceedings of Royal Society of London, Series B. Vol.283. P.20160140.

Stolzenberg D.S., Stevens J.S. \& Rissman E.F. 2012. Experience-facilitated improvements in pup retrieval; evidence for an epigenetic effect // Hormones and Behavior. Vol.62. P.128-135.

Storey A.E. \& Joyce T.L. 1995. Pup contact promotes paternal responsiveness in male meadow voles // Animal Behaviour. Vol.49. P.1-10.

Storey A.E. \& Snow D.T. 1987. Male identity and enclosure size effect paternal attendance of meadow voles, Microtus pennsilvanicus // Animal Behaviour. Vol.5. P.411-419.

Storey A.E., Bradbury C.G. \& Joyce T.L. 1994. Nest attendance in male meadow voles: the role of the female in regulating male interactions with pups // Animal Behaviour. Vol.47. P.1037-1046.

Sturgis J.D. \& Bridges R.S. 1997. N-methyl-DL-aspartic acid lesions on the medial preoptic area disrupt ongoing parental behavior in male rats // Physiology \& Behavior. Vol.62. P.305-310.
Szyf M. 2015. Nongenetic inheritance and transgenerational epigenetics // Trends in Molecular Medicine. Vol.21. P.134-144.

Trainor B.C. \& Marler C.A. 2001. Testosterone, paternal behavior, and aggression in the monogamous California mouse (Peromyscus californicus) // Hormones and Behavior. Vol.40. P.32-42.

Trainor B.C. \& Marler C.A. 2002. Testosterone promotes paternal behaviour in a monogamous mammal via conversion to oestrogen // Proceedings of Royal Society of London. Vol.269. P.823-829.

Trainor B.C., Bird I.M., Alday N.A., Schlinger B.A. \& Marler C.A. 2003. Variation in aromatase activity in the medial preoptic area and plasma progesterone is associated with the onset of paternal behavior // Neuroendocrinology. Vol.78. P.36-44.

Trivers R.L. 1972. Parental investment and sexual selection // Campbell B. (ed.). Sexual selection and the descent of man. Chicago: Aldine. P.136-179.

Turner J.D., Kirschner S.A., Molitor A.M., Evdokimov K. \& Muller C.P. 2015. Epigenetics // International encyclopedia of the social and behavioral sciences. 2nd ed. P.839-847.

Vella E.T., Evans C.C., Ng M.W. \& Wynne-Edwards K.E. 2005. Ontogeny of the transition from killer to caregiver in dwarf hamsters (Phodopus campbelli) with biparental care // Developmental Psychobiology. Vol.46. P.75-85.

Vom Saal F.S., Grant W.M., McMullen C.W. \& Laves K.S. 1983. High fetal estrogen concentrations: correlation with increased adult sexual activity and decreased aggression in male mice // Science. Vol.220. P.1306-1309.

Walsh C.J., Fleming A.S., Lee A. \& Magnusson J.E. 1996. The effects of olfactory and somatosensory desensitization on fos-like immunoreactivity in the brains of pup-exposed postpartum rats // Behavioral Neuroscience. Vol.110. P.134-153.

Walton J.M. \& Wynne-Edwards K.E., 1997. Paternal care reduces maternal hyperthermia in Djungarian hamsters (Phodopus campbelli) // Physiology \& Behavior. Vol.63. P.41-47.

Wang Z.X. \& De Vries G.J. 1993. Testosterone effects on paternal behavior and vasopressin immunoreactive projections in prairie voles (Microtus ochrogaster) // Brain Research. Vol.631. P.156-160.

Wang Z.X. \& Novak M.A. 1994. Alloparental care and the influence of father presence on juvenile prairie voles, Microtus ochrogaster // Animal Behaviour. Vol.47. P.282-288.

Wang Z., Ferris C.F. \& De Vries G.J. 1994. Role of septal vasopressin innervation in paternal behavior in prairie voles (Microtus ochrogaster) // Proceedings of National Academy of Sciences of USA. Vol.91. P.400-404.

Wang Z., Young L.J., De Vries G.J. \& Insel T.R. 1999. Voles and vasopressin: A review of molecular, cellular, and behavioral studies of pair bonding and paternal behaviors // Progress in Brain Research. Vol.119. P.483-499.

Wang Z.X., Liu Y. \& Insel T.R. 2000. Hypothalamic vasopressin gene expression increases in both males and females postpartum in a biparental rodent // Journal of Neuroendocrinology. Vol.12. P.111-120.

Wang L., Zhang W., Wu R., Kong L., Feng W., Cao Y., Tai F. \& Zhang X. 2014. Neuroendocrine responses to social 
isolation and paternal deprivation at different postnatal ages in mandarin voles // Developmental Psychobiology. Vol.56. P.1214-1228.

Wang P., Yang H.-P., Tian S., Wang L., Wang S., Zhang F. \& Wang Y.-F. 2015. Oxitocin-secreting system: a major part of the neuroendocrine center regulating immunologic activity // Journal of Neuroimmunology. Vol.289. P.152-161.

Wang B., Wang L., Wang K. \& Tai F. 2018. The effects of fathering experience on paternal behaviors and levels of central expression of oxytocin and dopamine-2 type receptors in mandarin voles // Physiology \& Behavior. Vol.193. P.35-42.

Waterman J. 2007. Male mating strategies in rodents // Wolff J.O. \& Sherman P.W. (eds.). Rodent Societies - An Ecological \& Evolutionary Perspective. Chicago: Univ. Chicago Press. P.27-41.

Weaver I.C. 2007. Epigenetic programming by maternal behavior and pharmacological intervention. Nature versus nurture: let's call the whole thing off // Epigenetics. Vol.2. P.22-28.

Weaver I.C., Cervoni F., Champagne A., D'Alessio S., Sharma J., Seckl S., Dymov M., Szyf M. \& Meany M. 2004. Epigenetic programming by maternal behavior // Nature Neuroscience. Vol.7. P.847-854.

Werren J.H., Gross M.R. \& Shine R., 1980. Paternity and the evolution of male parental care // Journal of Theoretical Biology. Vol.82. P.619-631.

West H.E. \& Capellini I. 2016. Male care and life history traits in mammals // Nature Communications. Vol.7. P.1-10.

Westnead D.F. \& Sherman P.W. 1993. Parentage and the evolution of parental behavior // Behavioral Ecology. Vol.4. P.66-77.

Wittenberger J.F. \& Tilson R.L. 1980. The evolution of monogamy: Hypotheses and evidence // Annual Review of Ecology and Systematics. Vol.11. P.197-232.

Wolff J.O. 1985. Social behaviour // Kirkland G.L. \& Layne J.N. (eds.) Advances in the Study of Peromyscus (Rodentia). Lubbock: Texas Tech Univ. Press. P.271-291.

Wolff J.O. 2003. Laboratory studies with rodents: Facts or artifacts // BioScience. Vol.53. P.421-427.

Wolf J.B., Brodie E.D., Cheverud J.M., Moore A.J. \& Wade M.J. 1998. Evolutionary consequences of indirect genetic effects // Trends in Ecology \& Evolution. Vol.13. P.64-69.

Woodroffe R. \& Vincent A. 1994. Mother's little helpers: Patterns of male care in mammals // Trends in Ecology \& Evolution. Vol.9. P.294-297.
Wright S.L. \& Brown R.E. 2002. The importance of paternal care on pup survival and pup growth in Peromyscus californicus when required to work for food // Behavioral Processes. Vol.60. P.41-52.

Wynne-Edwards K.E. 1995. Biparental care in Djungarian but not Siberian dwarf hamsters (Phodopus) // Animal Behaviour. Vol.50. P.1571-1585.

Wynne-Edwards K. E. 2001. Hormonal changes in mammalian fathers // Hormones and Behavior. Vol.40. P.139-145.

Wynne-Edwards K.E. 2003. From dwarf hamster to daddy: the intersection of ecology, evolution, and physiology that produces paternal behavior // Advances in the Study of Behavior. Vol.32. P.207-261.

Wynne-Edwards K.E. \& Reburn C.J. 2000. Behavioural endocrinology of mammalian fatherhood // Trends in Ecology and Evolution. Vol.15. P.464-468.

Wynne-Edwards K.E. \& Timonin M.E. 2007. Paternal care in rodents: Weakening support for hormonal regulation of the transition to behavioral fatherhood in rodent animal models of biparental care // Hormones and Behavior. Vol.52. P.114-121.

Xia X. \& Millar J.S. 1988. Paternal behavior by Peromyscus leucopus in enclosures // Canadian Journal of Zoology. Vol.66. P.1184-1187.

Yohn C.N., Leithead A.B. \& Becker E.A. 2017. Increased vasopressin expression in the BNST accompanies paternally induced territoriality in male and female California mouse offspring // Hormones and Behavior. Vol.93. P.9-17.

Young L.J. 1999. Oxytocin and vasopressin receptors and species-typical social behaviors // Hormones and Behavior. Vol.36. P.212-221.

Young L., Nilsen R., Waymire K.G., MacGregor G.R. \& Insel T.R. 1999. Increased affiliative response to vasopressin in mice expressing the V1a receptor from a monogamous vole // Nature. Vol.400. P.766-768.

Yu P., Zhang H., Li X., He F. \& Tai F. 2015. Early biparental separation or neonatal paternal deprivation in mandarin voles reduces adult offspring paternal behavior and alters serum corticosterone levels and neurochemistry // Hormones and Behavior. Vol.73. P.8-14.

Yuan W., He Z., Hou W., Wang L. \& Tai F. 2019. Role of oxytocin in the medial preoptic area (MPOA) in the modulation of paternal behavior in mandarin voles // Hormones and Behavior. V.110. P.46-55. 